\title{
Organosulfates and organic acids in Arctic aerosols: speciation, annual variation and concentration levels
}

\author{
A. M. K. Hansen ${ }^{1}$, K. Kristensen ${ }^{1}$, Q. T. Nguyen ${ }^{1,2}$, A. Zare ${ }^{1,2,3}$, F. Cozzi ${ }^{1}$, J. K. Nøjgaard ${ }^{2}$, H. Skov ${ }^{2,4}$, J. Brandt $^{2}$, \\ J. H. Christensen ${ }^{2}$, J. Ström ${ }^{5}$, P. Tunved ${ }^{5}$, R. Krejci ${ }^{5,6}$, and M. Glasius ${ }^{1}$ \\ ${ }^{1}$ Department of Chemistry and iNANO, Aarhus University, Aarhus, Denmark \\ ${ }^{2}$ Department of Environmental Science, Aarhus University, Roskilde, Denmark \\ ${ }^{3}$ Institute of Geophysics, University of Tehran, Tehran, Iran \\ ${ }^{4}$ University of Southern Denmark, Institute of Chemical Engineering and Biotechnology and Environmental Technology, \\ Odense, Denmark \\ ${ }^{5}$ Department of Applied Environmental Science, Stockholm University, Stockholm, Sweden \\ ${ }^{6}$ Department of Physics, University of Helsinki, Helsinki, Finland
}

Correspondence to: A. M. K. Hansen (annem@chem.au.dk)

Received: 19 December 2013 - Published in Atmos. Chem. Phys. Discuss.: 20 February 2014

Revised: 30 May 2014 - Accepted: 16 June 2014 - Published: 7 August 2014

\begin{abstract}
Sources, composition and occurrence of secondary organic aerosols in the Arctic were investigated at Zeppelin Mountain, Svalbard, and Station Nord, northeastern Greenland, during the full annual cycle of 2008 and 2010 , respectively. Speciation of organic acids, organosulfates and nitrooxy organosulfates - from both anthropogenic and biogenic precursors were in focus. A total of 11 organic acids (terpenylic acid, benzoic acid, phthalic acid, pinic acid, suberic acid, azelaic acid, adipic acid, pimelic acid, pinonic acid, diaterpenylic acid acetate and 3-methyl1,2,3-butanetricarboxylic acid), 12 organosulfates and 1 nitrooxy organosulfate were identified in aerosol samples from the two sites using a high-performance liquid chromatograph (HPLC) coupled to a quadrupole Time-of-Flight mass spectrometer. At Station Nord, compound concentrations followed a distinct annual pattern, where high mean concentrations of organosulfates $\left(47 \pm 14 \mathrm{ng} \mathrm{m}^{-3}\right)$ and organic acids $\left(11.5 \pm 4 \mathrm{ng} \mathrm{m}^{-3}\right)$ were observed in January, February and March, contrary to considerably lower mean concentrations of organosulfates $\left(2 \pm 3 \mathrm{ng} \mathrm{m}^{3-}\right)$ and organic acids $\left(2.2 \pm 1 \mathrm{ng} \mathrm{m}^{-3}\right)$ observed during the rest of the year. At Zeppelin Mountain, organosulfate and organic acid concentrations remained relatively constant during most of the year at a mean concentration of $15 \pm 4 \mathrm{ng} \mathrm{m}^{-3}$ and $3.9 \pm 1 \mathrm{ng} \mathrm{m}^{-3}$, respectively. However during four weeks of spring, remarkably higher concentrations of total organosulfates $\left(23-36 \mathrm{ng} \mathrm{m}^{-3}\right)$
\end{abstract}

and total organic acids (7-10 $\mathrm{ng} \mathrm{m}^{-3}$ ) were observed. Elevated organosulfate and organic acid concentrations coincided with the Arctic haze period at both stations, where northern Eurasia was identified as the main source region. Air mass transport from northern Eurasia to Zeppelin Mountain was associated with a $100 \%$ increase in the number of detected organosulfate species compared with periods of air mass transport from the Arctic Ocean, Scandinavia and Greenland. The results from this study suggested that the presence of organic acids and organosulfates at Station Nord was mainly due to long-range transport, whereas indications of local sources were found for some compounds at Zeppelin Mountain. Furthermore, organosulfates contributed significantly to organic matter throughout the year at Zeppelin Mountain (annual mean of $13 \pm 8 \%$ ) and during Arctic haze at Station Nord $(7 \pm 2 \%)$, suggesting organosulfates to be important compounds in Arctic aerosols.

\section{Introduction}

It is well known that the Arctic environment is sensitive to changes in the radiative balance. Within the last 100 years the atmospheric temperature in the Arctic has increased by 2 to $3{ }^{\circ} \mathrm{C}$, which is twice the global average (IPCC, 2013; ACIA, 2004). This enhancement in temperature has resulted 
in increased melting of sea ice and thawing of permafrost, which in turn decrease surface albedo, thereby further impacting the radiative balance of the region through positive feedback processes (Hudson, 2011). Atmospheric aerosols are key constituents of the climate system, influencing the radiative balance of Earth directly by absorbing and reflecting radiation (Charlson et al., 1992) and indirectly by acting as cloud condensation nuclei $(\mathrm{CCN})$ affecting the formation and lifetime of clouds (Albrecht, 1989). In the Arctic, low-altitude liquid clouds warm the surface during winter as they trap and re-emit outgoing long-wave radiation more efficiently than they reflect the incoming short-wave radiation (Bennartz et al., 2013; Shupe and Intrieri, 2004). The formation of low-altitude liquid clouds thus has a warming effect on the surface throughout most of the year in the Arctic, except for a short period in summer, when a net cooling is observed (Intrieri et al., 2002; Walsh and Chapman, 1998). Thus, the presence of aerosols that can act as CCN may have a warming effect on the Arctic environment during winter.

In the Arctic atmosphere, the aerosol loading is highly seasonal, as recently shown by Tunved et al. (2013) in a study investigating Arctic aerosol life cycle based on a 10-year data set from Zeppelin Mountain, Svalbard. In the mentioned study an increased atmospheric mass loading was observed during late winter and spring compared to summer and autumn. Increased mass loading has previously been assigned to occur during winter and spring due to expansion of the polar air dome to include parts of Eurasia and North America (Ottar, 1989), intensifying the meridional air transport from the mid-latitudes to the Arctic (Iversen and Joranger, 1985; Austin, 1980; Solgaard et al., 1979). In addition, the polar night causes the Arctic atmosphere to stabilize due to strong surface-based temperature inversions. The stable atmosphere inhibits turbulent transfer between the atmospheric layers as well as the major aerosol removal processes, e.g. formation of clouds and precipitation (Barrie et al., 1981; Shaw, 1981, 1995; Heintzenberg and Larssen, 1983; Heidam, 1981), thus trapping the pollutants in the Arctic atmosphere for up to 1530 days (Shaw, 1981, 1995). The air pollution can be visible as distinct haze bands, known as Arctic haze. The primary source regions of Arctic haze have been identified as northern Eurasia through chemical fingerprint analysis and air transport modelling (Nguyen et al., 2013; Stohl et al., 2007; Treffeisen et al., 2007; Heidam et al., 2004; Christensen, 1997; Pacyna et al., 1985; Shaw, 1982; Rahn, 1981). Chemical analyses have shown that the haze aerosols primarily consist of sulfate and organic matter in addition to nitrate, ammonium, dust, trace heavy metals and soot (Fenger et al., 2013; Nguyen et al., 2013; Heidam et al., 1999, 2004; Iversen and Joranger, 1985; Pacyna et al., 1985; Barrie et al., 1981; Rahn et al., 1977). The reflection, absorption and CCN properties of aerosols are highly dependent on the chemical composition as well as particle size (Lohmann and Feichter, 2005; Andreae et al., 2004). However, there is a lack of knowledge on the composition of organic aerosols, especially the secondary organic aerosol (SOA) component. Hence, in this study, chemical speciation of three classes of molecular SOA tracers, namely organic acids, organosulfates and nitrooxy organosulfates, is in focus. Furthermore the anthropogenic and biogenic contribution to SOA is investigated.

Organic acids, which are often semi-volatile and water soluble, are formed through atmospheric oxidation of volatile organic compounds (VOCs) (Hallquist et al., 2009; Glasius et al., 2000). They contribute to the formation of SOA by condensation onto pre-existing particles and by dissolving in the water film, thereby coating existing particles (Hallquist et al., 2009). Organic acids have previously been quantified in the Arctic atmosphere, with a mean annual concentration of individual species generally below $1 \mathrm{ng} \mathrm{m}^{-3}$ (Fu et al., 2009; Kawamura et al., 2005). Organosulfates and nitrooxy organosulfates are low-volatility SOA constituents, most likely formed from acid-catalysed particle phase reactions of epoxides with inorganic sulfate (Lin et al., 2012; Surratt et al., 2010; Minerath and Elrod, 2009). Both smog chamber experiments and ambient aerosol samples show that isoprene and monoterpenes are precursors of organosulfates in the atmosphere (Surratt et al., 2008; Iinuma et al., 2007). Since sulfate in the atmosphere primarily originates from anthropogenic sources (e.g. Zhang et al., 2009), the presence of organosulfates in ambient aerosols suggests an anthropogenic enhancement of the formation of biogenic SOA (BSOA) (Hoyle et al., 2011). Only one previous study has suggested the presence of organosulfates in the Arctic (Frossard et al., 2011) based on observations of organic sulfate functional groups in Arctic aerosol samples. However, no chemical speciation of organosulfates in the Arctic has been made.

This study aims to investigate speciation, occurrence and annual variation in concentrations of organosulfates and organic acids in the Arctic, analysing aerosol samples collected at two Arctic sites: Zeppelin Mountain, Svalbard, during 2008 and Station Nord, northeastern Greenland, during 2010.

\section{Experimental}

\subsection{Sampling}

The aerosol samples used in this study were collected at two Arctic sites: Station Nord, Greenland $\left(81^{\circ} 36^{\prime} \mathrm{N}, 16^{\circ} 40^{\prime} \mathrm{W}\right.$; $24 \mathrm{~m}$ a.s.l.) and Zeppelin Mountain, Svalbard $\left(78^{\circ} 56^{\prime} \mathrm{N}\right.$, $11^{\circ} 53^{\prime} \mathrm{E} ; 474 \mathrm{~m}$ a.s.l.).

The measurement site at Station Nord is located in the northeastern part of Greenland in a remote area $924 \mathrm{~km}$ from the North Pole, at a small military camp, representing a "natural high-Arctic station" (Nguyen et al., 2013; Skov et al., 2004). The site is dominated by winds from southwesterly directions and is probably influenced by local topography of katabatic winds from ice caps in the fjord southwest of 
the station (Nguyen et al., 2013). Atmospheric monitoring at Station Nord is carried out by the Danish Centre for Environment and Energy and the Department of Environmental Science, Aarhus University, as the Danish contribution to the atmospheric part of the Arctic Monitoring and Assessment Programme (AMAP). In this study, weekly samples of $\mathrm{PM}_{10}$ were collected on quartz fibre filters (Advantec, Toyo Roshi Kaisha Ltd., diameter $150 \mathrm{~mm}$ ) every fourth week during the entire year 2010 using a high-volume sampler (HVS) (Digitel DHA-80, Reimer Messtechnik, Switzerland). To avoid problems with the harsh weather, the HVS including the $\mathrm{PM}_{10}$ head was placed indoors in a building located within the military station and was furthermore equipped with a heated outdoor sampling head. Each sample corresponds to $5000 \mathrm{~m}^{3}$ air. After sampling, the filters were wrapped in aluminium foil and stored at $-20^{\circ} \mathrm{C}$ until extraction in 2012 .

The Zeppelin station is located on a mountain ridge overlooking the small settlement of $\mathrm{Ny} \AA$ Alesund. Due to its mountain location, Zeppelin station is mostly unaffected by local contamination from $\mathrm{Ny}$ Ålesund and can be considered to represent remote Arctic conditions. The Zeppelin station is confined within the boundary layer most of the time, but on occasions the top of the boundary layer is below the station altitude exposing the station to the lowermost free troposphere (Tunved et al., 2013). Local wind is dominated by east-southeast directions due to katabatic flow from the Kongsvegen glacier and additionally influenced by local orography (Hirdman et al., 2010; Beine et al., 2001). The station is owned by the Norwegian Polar Research Institute (NP), with the Norwegian Institute for Air Research (NILU) coordinating the scientific programme. At the station the Department of Applied Environmental Science (ITM), Atmospheric Science Unit, Stockholm University, carries out aerosol microphysical and optical properties measurements as well as routinely collecting weekly samples of total suspended particulate matter (TSP) on quartz fibre filters (Munktell \& Filtrak GmbH, diameter 47 mm, grade T293) using a Leckel Sequential Sampler SEQ 47/50 (Leckel $\mathrm{GmbH}$, Germany). In this study TSP samples from every second week of year 2008 were selected to keep the number of samples manageable and still obtain information on the annual cycle. Each sample corresponds to $210 \mathrm{~m}^{3}$ of air. After sampling, the filters were stored in Petri dishes, wrapped in aluminum foil and stored at $-20^{\circ} \mathrm{C}$ until extraction in 2012 .

\subsection{SOA analysis}

SOA extraction and analysis was based on the method of Kristensen and Glasius (2011). The collected aerosol filters were extracted by sonication in $10 \mathrm{~mL} 90 \%$ acetonitrile/10\% Milli-Q water in a cooled ultrasonic bath for $30 \mathrm{~min}$. Each filter was extracted twice and the resulting extracts were combined, filtered through a Teflon filter $(0.45 \mu \mathrm{m}$ pore size, Chromafil) and evaporated until dryness using a rotary evaporator. Each sample was re-dissolved twice in $0.5 \mathrm{~mL}$ Milli-
Q water with $3 \%$ acetonitrile and $0.1 \%$ acetic acid. All prepared samples were stored in a refrigerator at $3-5^{\circ} \mathrm{C}$ until analysis.

To monitor the efficiency of the extraction of the organic acids, organosulfates and nitrooxy organosulfates, a recovery standard (RSTD) of camphoric acid was added onto each filter before extraction. A mean recovery of $87 \pm 13 \%$ was obtained for all samples. Recovery percentages of the internal standard (ISTD) have been included in the calculation of the concentrations of organic acids and organosulfates, the reported concentrations corresponding to a $100 \%$ recovery.

All sample extracts were analysed on a Dionex UltiMate 3000 HPLC coupled to a quadrupole time-of-flight (qTOF) mass spectrometer from Bruker Daltonics (Bremen, Germany) through an electrospray ionization (ESI) inlet. Data were acquired and processed using Bruker Compass software.

The HPLC stationary phase was an Atlantis T3 $3 \mu \mathrm{m}$ $(150 \times 2.1 \mathrm{~mm})$ column from Waters and the mobile phase consisted of $0.1 \%(v / v)$ acetic acid (eluent A) and $95 \%$ $(v / v)$ acetonitrile (eluent B). The applied gradient was a 57 min multistep gradient with the following course: eluent $\mathrm{B}$ increased from 3 to $20 \%$ within the first $20 \mathrm{~min}$. B increased to $60 \%$ in $10 \mathrm{~min}$, and then to $90 \%$ in $5 \mathrm{~min}$, held at $90 \%$ B for 10 min then increased to $100 \%$ B within $1 \mathrm{~min}$, held at $100 \% \mathrm{~B}$ in $5 \mathrm{~min}$, and finally decreased to $3 \% \mathrm{~B}$ within $3 \mathrm{~min} ; 3 \% \mathrm{~B}$ held during the remaining $3 \mathrm{~min}$. The injected sample volume was $10 \mu \mathrm{L}$ and the flow rate was $0.2 \mathrm{~mL} \mathrm{~min}^{-1}$. The ESI-q-TOF mass spectrometer (MS) was operated in negative ionization mode under the following conditions: nebulizer pressure at 3.4 bar, dry gas flow $8.0 \mathrm{~mL} \mathrm{~min}^{-1}$, collision energy $6.0 \mathrm{eV}$, collision RF 120 and transfer time $50.0 \mu \mathrm{s}$.

Organic acids were identified and quantified using authentic standards. Organosulfates and nitrooxy organosulfates were identified from their loss of $\mathrm{SO}_{3}^{-}(\mathrm{m} / z=80)$ or $\mathrm{HSO}_{4}^{-}(m / z=97)$ and an additional neutral loss of $\mathrm{HNO}_{3}$ $(m / z=63)$ in the case of nitrooxy organosulfates (Surratt et al., 2007). Organosulfates were quantified using an authentic $\beta$-pinene organosulfate standard (synthesized in-house according to a method described by Iinuma et al. (2009) followed by purification using medium-pressure liquid chromatography (MPLC)), while nitrooxy organosulfates were quantified using a surrogate standard of octyl sulfate (Sigma Aldrich), chosen due to similar chromatographic retention time as the identified nitrooxy organosulfate.

A linear relation between peak area and concentration was established and applied for quantification of pimelic acid, benzoic acid, azelaic acid, suberic acid, cis-pinic acid, terpenylic acid, $\beta$-pinene (organosulfate standard, OS surrogate) and octyl sulfate (nitrooxy organosulfate standard, NOS surrogate). A quadratic relation between peak area and concentration was established and applied for quantification of adipic acid, phthalic acid, pinonic acid, diaterpenylic acid 
acetate (DTAA) and 3-methyl-1,2,3-butanetricarboxylic acid (MBTCA). The correlation coefficients $R^{2}$ of all calibration curves were better than 0.99 ( $n=8$ data points) and detection limits of all compounds fall within the interval of 0.01$0.33 \mathrm{ng} \mathrm{m}^{-3}$.

Regarding uncertainties on the measurements, it is estimated that the total uncertainty on the organic acid and organosulfate concentrations is approximately $15 \%$. This estimate is based upon analytical errors (calibration curve and laboratory equipment), uncertainty on the extraction efficiency and uncertainty on the collected air volume.

\subsection{Supplementary analysis}

Samples for analysis of organic and elemental carbon (OC/EC) in atmospheric aerosol were collected at Zeppelin station. The OC/EC analysis was carried out with a thermal optical transmittance (TOT) method using a thermal-optical carbon aerosol analyser (Sunset Laboratory Inc., USA) following the NIOSH method 5040. Details about the OC/EC analysis can be found in Krecl et al. (2007). Non-sea-salt sulfate (nss-sulfate) measurements have been obtained from EBAS and are publicly available at http://ebas.nilu.no.

Measurements of OC and nss-sulfate were also performed as supporting analyses for the Station Nord samples. OC was measured directly on the collected quartz fibre samples using a thermal optical transmittance (TOT) method following the EU standard OC/EC protocol 2008 European Supersites for Atmospheric Aerosol Research (EUSAAR-2) (Cavalli et al., 2010). Non-sea-salt sulfate was determined by subtracting sea salt $\mathrm{SO}_{4}^{2-}$ from total $\mathrm{SO}_{4}^{2-}$. Sea salt $\mathrm{SO}_{4}^{2-}$ was calculated from the ion ratio $\mathrm{SO}_{4}^{2-} / \mathrm{Na}^{+}$in seawater equal to 0.252 , assuming that all $\mathrm{Na}^{+}$in aerosols originated from sea salt (Sciare et al., 2003; Rankin et al., 2002). $\mathrm{Na}^{+}$and $\mathrm{SO}_{4}^{2-}$ were measured using ion chromatography/dual-ion chromatography.

\subsection{Backwards air mass trajectory analysis}

Air mass transport and origin was analysed using the HYSPLIT (HYbrid Single-Particle Lagrangian Integrated Trajectory) backwards air parcel model (Draxler and Hess, 1998). Meteorological data from GDAS were used as input for the model. Each filter sample corresponds to seven days of aerosol sampling every fourth week at Station Nord and every second week at Zeppelin Mountain. For each filter sample from both stations, trajectories were calculated $120 \mathrm{~h}$ backwards in time every fourth hour for the seven sampling days at 10, 1500 and $3000 \mathrm{~m}$ arrival heights (above ground level) and cluster analyses of the back trajectories were performed.

\subsection{Modelling of biogenic volatile organic compound emissions}

In this study, the global Model of Emissions of Gases and Aerosols from Nature (MEGAN) was used to estimate emissions of the biogenic VOC (BVOC) (Guenther et al., 2006).

The MEGAN model estimates the emission rate of isoprene based on empirical relationships for key drivers of temperature, radiation, soil moisture, leaf area index and foliage age. These activity factors account for the isoprene emission factor response to the environmental conditions. The emission factors are the plant functional type (PFT)- dependent isoprene emission rates at the standard conditions. Here, we used the MEGAN v2.04 data set, which comprises the geographical distribution of both the fractional cover and the emission factor for six PFTs: broadleaf tree, needle leaf evergreen tree, needle leaf deciduous tree, shrub, and crop. Each area of the Earth's land surface in the model domain is assigned to a fraction of these PFTs. In general, the emission model MEGAN calculates the total flux of isoprene within every grid cell as the sum of emissions from each PFT.

The empirical algorithm of MEGAN is conducted similarly to calculate hourly emission rates of monoterpenes. However, due to the ability of monoterpenes to be stored in the plant, MEGAN describes the effect of radiation on the monoterpene emission rates based on an alternative process (Sakulyanontvittaya et al., 2008). MEGAN uses a lightdependence fraction to take into account the fraction of monoterpene emissions influenced by light intensity. Furthermore, the response of monoterpene emission rates to the temperature is also parametrized in a simple and different approach from the isoprene one (Sakulyanontvittaya et al., 2008).

The monoterpene emission rates are a summation of calculated emission rates for seven monoterpene compounds ( $\alpha$-pinene, $\beta$-pinene, ocimene, limonene, sabinene, myrcene, and delta3-carene) by the MEGAN model.

The required meteorological data for running MEGAN are provided by the mesoscale meteorological model MM5v3.7, using the required initial and boundary conditions, derived from NCEP Final Analyses data (http://rda.ucar.edu/datasets/ ds083.2/).

Recently the performance of this emission model with coupling into the chemistry transport model DEHM (Danish Eulerian Hemispheric Model) (Brandt et al., 2012) was evaluated. The results showed a relatively good agreement with available observations at measuring sites in Europe and North America for simulation of both isoprene and monoterpene concentrations (Zare et al., 2012, 2014). 


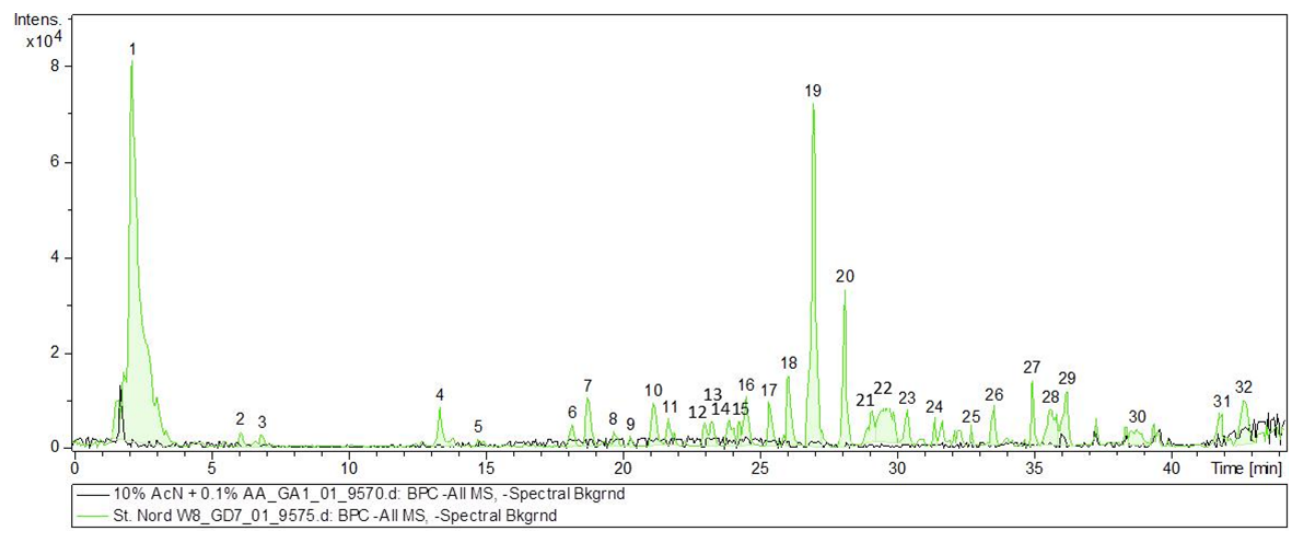

Figure 1. Chromatogram of the SOA sample from Station Nord week 8 (in green). A blank filter sample is shown in black. The SOA products giving rise to each peak are identified as follows: 1, sulphate dimer; 2 and 3, OS 140; 4, OS 154; 5, OS 196a; 6, terpenylic acid; 7, phthalic acid; 8, terephthalic acid; 9, pimelic acid; 10, unknown; 11 and 13, OS 168, 12 and 24, pinic acid; 14, OS 180; 15, DTAA; 16, unknown; 17, suberic acid; 18, unknown; 19, internal standard; 20, azelaic acid; 21 and 23, OS 182; 22, OS 208; 25, OS 250; 26 and 28, OS $196 \mathrm{~b} ; 27$ and 29, unknown $m / z 293$; 30, OS 196b; 31, NOS 295; and 32. OS 210.

\section{Results and discussion}

\subsection{Identified compounds}

Figure 1 shows a typical chromatogram obtained from HPLC-q-TOF-MS analysis of the aerosol samples. Good separation of chromatographic peaks was obtained for most compounds, and only five of the observed peaks remained unidentified from our analysis. A total of 24 different SOA tracers were identified including 11 organic acids (terpenylic acid, benzoic acid, phthalic acid (given as the sum of phthalic acid and terephthalic acid), pinic acid, suberic acid, azelaic acid, adipic acid, pimelic acid, pinonic acid, DTAA and MBTCA), 12 organosulfates (molecular weight 140, 154, 168, 180, 182, 196a, 196b, 208, 210, 224, 250 and 280) and 1 nitrooxy organosulfate (MW 295). All of the observed organic acids have previously been reported as atmospheric trace constituents. In this study all organic acids are categorized into anthropogenic (benzoic acid, phthalic acid, adipic acid and pimelic acid) and biogenic (terpenylic acid, DTAA, pinic acid, pinonic acid, MBTCA, suberic acid and azelaic acid) tracers based on previous studies of their atmospheric formation and precursors (Williams et al., 2010; Claeys et al., 2009; Rybka et al., 2007; Ma et al., 2007; Mochida et al., 2003; Bunce et al., 1997; Hatakeyama et al., 1987). However, pimelic acid, here assigned to be an anthropogenic tracer, may be of biogenic origin as well, derived from the oxidation of unsaturated fatty acids (Kawamura and Gagosian, 1987). In Table S1 in the Supplement an overview of the structures and suggested precursors of the carboxylic acids is given. The organosulfates are less studied, this being the first investigation of their speciation in the Arctic. The suggested molecular formulas, structures and precursors of the organosulfates identified in this study are listed in Table 1.

\subsubsection{OS 140, OS 154, OS 168 and OS 182}

Of the organosulfates observed in Arctic aerosols, four have previously been identified as isoprene tracers, namely OS 140, OS 154, OS 168 and OS 182. Smog chamber studies of photochemical oxidation of isoprene in the presence of acidic sulfate aerosols showed formation of multiple organosulfates including OS 140, OS 154, OS 168 and OS 182, which have been hypothesized to originate from the isoprene degradation products: glycolaldehyde, hydroxyacetone, methacrolein and 2-methylglyceric acid, respectively (Surratt et al., 2007; Szmigielski et al., 2007).

In order to investigate potential sources, emissions of isoprene during each month of 2008 were modelled using the MEGAN model (Fig. 2). The model results show negligible emissions in the Arctic and the mid-latitudes in the period November to March $\left(<1.0 \mathrm{mg} \mathrm{m}^{-2}\right.$ week $\left.^{-1}\right)$ compared to June to August (approximately $100-300 \mathrm{mg} \mathrm{m}^{-2}$ week $^{-1}$ ). The low winter and spring emissions of isoprene at midlatitudes obtained by the MEGAN model are in very close agreement with results of Hakola et al. (2009), who studied emissions from Scots pine, and Guenther (1997), who reviewed measurements of isoprene from deciduous trees. The highest concentrations of OS 140, OS 154, OS 168 and OS 182 are, however, observed during winter and spring at both Station Nord (Sect. 3.2) and Zeppelin Mountain (Sect. 3.3).

As considerable isoprene emissions occur in the tropics during winter and spring, it is possible that transport from the tropics with uplift outside the Arctic followed by descent into the Arctic through the upper troposphere/lower stratosphere (Stohl, 2006) could account for the observation of OS 140, OS 154, OS 168 and OS 182 from isoprene degradation at the Arctic sites. However, during winter and spring the Arctic troposphere is very stratified, and this source is not likely to explain concentrations observed at the surface and lower 
Table 1. The observed organosulfates and nitrooxy organosulfates. Measured $m / z$, molecular weight, retention time, MSMS fragments, molecular formula, possible structure and suggested precursor are given. (a) Surratt et al. (2007), (b) Surratt et al. (2008).

\begin{tabular}{|c|c|c|c|c|c|c|c|}
\hline & $\begin{array}{c}\text { Measured } \\
\mathrm{m} / \mathrm{z}\end{array}$ & $\begin{array}{l}\text { MW } \\
\text { (Da) }\end{array}$ & $\begin{array}{c}\mathrm{RT} \\
\text { (min.) }\end{array}$ & $\begin{array}{c}\text { MSMS } \\
\text { fragments }\end{array}$ & Molecular formula & Possible structure & Suggested precursor \\
\hline OS 140 & 139.002 & 140.010 & $6.2 ; 7.3$ & $96.96 ; 79.96$ & $\begin{array}{c}\mathrm{C}_{2} \mathrm{H}_{4} \mathrm{O}_{5} \mathrm{~S} \\
\text { Exact mass: } 139.978\end{array}$ & & glycolaldehyde $\mathrm{e}^{\mathrm{a}, \mathrm{b}}$ \\
\hline OS 154 & 153.020 & 154.028 & 13.4 & $96.96 ; 79.96$ & $\begin{array}{c}\mathrm{C}_{3} \mathrm{H}_{6} \mathrm{O}_{5} \mathrm{~S} \\
\text { Exact mass: } 153.994\end{array}$ & & hydroxyacetone $e^{\mathrm{a}, \mathrm{b}}$ \\
\hline OS 168 & 167.043 & 168.051 & $21.7 ; 23.2$ & $\begin{array}{c}121.02 \\
96.96 ; 79.96\end{array}$ & $\begin{array}{c}\mathrm{C}_{4} \mathrm{H}_{8} \mathrm{O}_{5} \mathrm{~S} \\
\text { Exact mass: } 168.009\end{array}$ & & Methacrolein $^{\mathrm{a}}$ \\
\hline OS 180 & 179.023 & 180.031 & 24.0 & $96.95 ; 79.96$ & $\begin{array}{c}\mathrm{C}_{5} \mathrm{H}_{8} \mathrm{O}_{5} \mathrm{~S} \\
\text { Exact mass: } 180.009\end{array}$ & wn & Unknown \\
\hline OS 182 & 181.043 & 182.052 & $29.1 ; 30.3$ & $96.95 ; 79.96$ & $\begin{array}{c}\mathrm{C}_{5} \mathrm{H}_{10} \mathrm{O}_{5} \mathrm{~S} \\
\text { Exact mass: } 182.025\end{array}$ & & $\begin{array}{l}\text { 2-methylglyceric } \\
\operatorname{acid}^{\mathrm{a}}\end{array}$ \\
\hline OS 196a & 195.029 & 196.037 & $12.8 ; 15.0$ & 96.96 & $\begin{array}{c}\mathrm{C}_{6} \mathrm{H}_{12} \mathrm{O}_{5} \mathrm{~S} \\
\text { Exact mass: } 196.041\end{array}$ & own & Unknown \\
\hline OS 196b & 195.064 & 196.078 & $35.5 ; 38.7$ & $96.96 ; 79.96$ & $\begin{array}{c}\mathrm{C}_{6} \mathrm{H}_{12} \mathrm{O}_{5} \mathrm{~S} \\
\text { Exact mass: } 196.041\end{array}$ & Unknown & Unknown \\
\hline OS 208 & 206.996 & 208.004 & $29.4 ; 30.2$ & $96.96 ; 79.96$ & $\begin{array}{c}\mathrm{C}_{6} \mathrm{H}_{8} \mathrm{O}_{6} \mathrm{~S} \\
\text { Exact mass: } 208.004\end{array}$ & Unknown & Unknown \\
\hline OS 210 & 209.090 & 210.098 & 42.5 & 96.96 & $\begin{array}{c}\mathrm{C}_{7} \mathrm{H}_{14} \mathrm{O}_{5} \mathrm{~S} \\
\text { Exact mass: } 210.056\end{array}$ & Unknown & Unknown \\
\hline OS 224 & 223.110 & 224.118 & 45.1 & 96.96 & $\begin{array}{c}\mathrm{C}_{8} \mathrm{H}_{16} \mathrm{O}_{5} \mathrm{~S} \\
\text { Exact mass: } 224.072\end{array}$ & Unknown & Unknown \\
\hline OS 250 & 249.073 & 250.081 & 32.4 & 96.96 & $\begin{array}{c}\mathrm{C}_{10} \mathrm{H}_{18} \mathrm{O}_{5} \mathrm{~S} \\
\text { Exact mass: } 250.087\end{array}$ & & $\alpha-/ \beta$-pinene ${ }^{b}$ \\
\hline & & & & & & More isomers & \\
\hline OS 280 & 279.050 & 280.058 & $22.2 ; 27.7$ & $\begin{array}{c}199.093 \\
164.982 ; \\
96.96 ; 79.96\end{array}$ & $\begin{array}{c}\mathrm{C}_{10} \mathrm{H}_{16} \mathrm{O}_{7} \mathrm{~S} \\
\text { Exact mass: } 280.062\end{array}$ & & $\alpha-/ \beta$-pinene ${ }^{b}$ \\
\hline NOS 295 & 294.063 & 295.071 & $41.4 ; 44,7$ & $\begin{array}{c}247.056 \\
231.06 \\
96.96\end{array}$ & $\begin{array}{c}\mathrm{C}_{10} \mathrm{H}_{17} \mathrm{O}_{7} \mathrm{NS} \\
\text { Exact mass: } 295.073\end{array}$ & & $\alpha-/ \beta$-pinene ${ }^{b}$ \\
\hline
\end{tabular}

part of the troposphere. Backwards air mass trajectory analysis using the HYSPLIT model (see the Supplement) was performed to study vertical mixing across the boundary layer for specific periods. The results showed no considerable difference in the degree of vertical mixing during the sampling periods with high concentrations of OS 140, OS 154, OS 168 and OS 182 and during weeks when none of the isoprene organosulfates were present, indicating that transport from the tropics through the upper troposphere/lower stratosphere is an unlikely source. If OS 140, OS 154, OS 168 and OS 182 observed in the Arctic aerosols were solely from isoprene degradation, a relatively constant ratio between them would furthermore be expected; this was, however, not the case. The ratio between the four organosulfates varied over 3 orders of magnitude between the different samples; thus other sources of OS 140, OS 154, OS 168 and OS 182 are expected.
Several studies suggest that glycolaldehyde, hydroxyacetone, methacrolein and 2-methylglyceric acid originate from biomass burning, field burning of agriculture wastes, and anthropogenic sources such as automobiles and fossil fuel combustion as well as photooxidation of isoprene (Myriokefalitakis et al., 2008; Surratt et al., 2008; Hakola et al., 2009; Biesenthal and Shepson, 1997; Tuazon and Atkinson, 1990; Zhang et al., 2012; Kawamura et al., 2013). Considering the relatively low emissions of isoprene (Fig. 2) during winter and early spring in the Arctic and in the northernmost part of Eurasia (the main source region for Arctic haze), the variability of the ratios between OS 140, OS 154, OS 168 and OS 168 , and the lack of indication of transport from the tropics, we propose that OS 140, OS 154, OS 168 and OS 182 in the Arctic aerosols primarily originate from anthropogenic emissions from combustion of fossil fuels and biomass burning. 


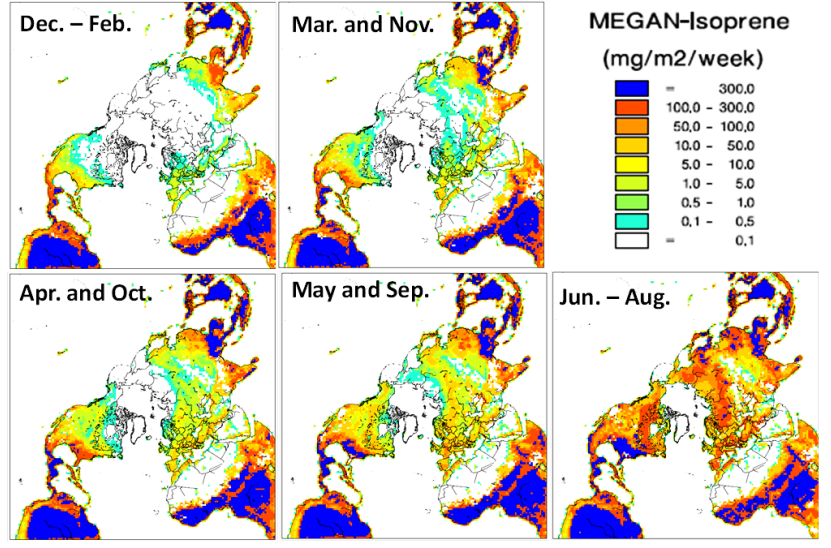

Figure 2. Spatial distribution of the simulated isoprene emission from the MEGAN model for the year 2008. Months with similar emissions are represented by the same map.

\subsubsection{OS 250, OS 280 and NOS 295}

Smog chamber studies of photooxidation of $\alpha$ - $/ \beta$-pinene and limonene have identified monoterpenes as important precursors of OS 250, OS 280 and NOS 295 (Surratt et al., 2007, 2008; Iinuma et al., 2007). Recently, residential wood combustion has also been suggested as a source of NOS 295 and organosulfates during winter (Kahnt et al., 2013). In the chamber experiments other organosulfates and nitrooxy organosulfates were identified as well, three of which were also detected in our Arctic aerosol samples (OS 238, OS 265, NOS 310); however, all three compounds were below the detection limit and will not be mentioned further.

Emissions of monoterpenes were modelled during summer, autumn, winter and spring using the MEGAN model. In contrast to isoprene, emissions of monoterpene are not only confined to the growing season but occur throughout the year (Hakola et al., 2009). The model results showed emission rates of up to $20 \mathrm{mg} \mathrm{m}^{-2}$ week $^{-1}$ during winter and early spring (November to April) at midlatitudes, which is approximately one-fifth of the emission rates observed during summer and autumn (May to October, $40-60 \mathrm{mg} \mathrm{m}^{-2}$ week $^{-1}$ ). The regions with adequately high monoterpene emissions are also common source regions for air masses arriving at the sites during Arctic winter and early spring.

\subsubsection{OS 180, OS 196a, OS 196b, OS 208, OS 210 and OS 224}

Six of the Arctic organosulfates, namely OS 180, OS 196a, OS 196b, OS 208, OS 210 and OS 224, have not been previously reported in either smog chamber or ambient studies.

Until now, smog chamber experiments have focused on formation of organosulfates from isoprene, monoterpenes and sesquiterpenes, which all generate multiple organosul-

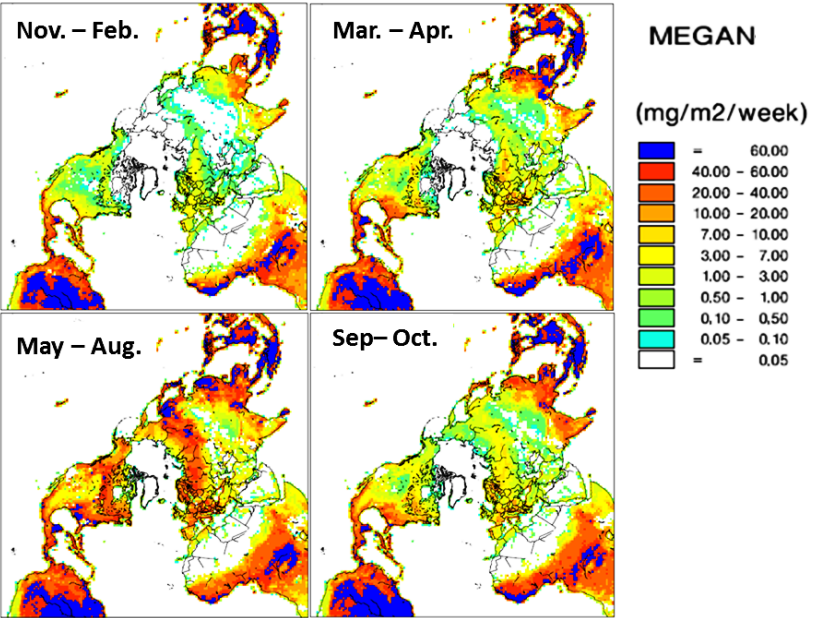

Figure 3. Spatial distribution of the simulated monoterpene emission from the MEGAN model during the year of 2008.

fates (Iinuma et al., 2007; Surratt et al., 2008; GómezGonzàlez et al., 2008; Chan et al., 2011). Isoprene and monoterpenes have especially been identified as the dominant precursors of organosulfates in atmospheric aerosols during summer periods in temperate and subtropical areas (Kristensen and Glasius, 2011; Stone et al., 2012; Surratt et al., 2008).

Based on the fact that the unknown organosulfates have not been identified in smog chamber experiments with isoprene, limonene and $\alpha-/ \beta$-pinene, it is unlikely that these compounds are the unidentified precursors.

Possible precursors could be of anthropogenic origin or from marine sources (which have not yet been studied), but further studies are needed to elucidate this matter.

Based on the measured masses of the compounds we have included the most likely molecular formulas of OS 180, OS 196a, OS 196b, OS 208, OS 210 and OS 224 in Table 1, while structures and precursors are not listed for these six compounds as they have not yet been identified.

\subsection{Station Nord}

Figure 4 shows the annual variation in concentrations of organic acids, organosulfates and nitrooxy organosulfates at Station Nord in 2010. A distinct annual pattern, especially in concentration levels of the organosulfates, was identified. From week 4 (January) to week 12 (March) the mean concentration of total organosulfate compounds was 47.4 $( \pm 14) \mathrm{ng} \mathrm{m}^{-3}$, a concentration 2 orders of magnitude higher than that observed during the rest of the year (mean concentration of $\left.2.1( \pm 3) \mathrm{ng} \mathrm{m}^{-3}\right)$. The organic acids showed the same seasonal trend, but with less clear differences in concentration levels, with a mean concentration of total organic acids of $11.5( \pm 4) \mathrm{ng} \mathrm{m}^{-3}$ from weeks 4 to 12 


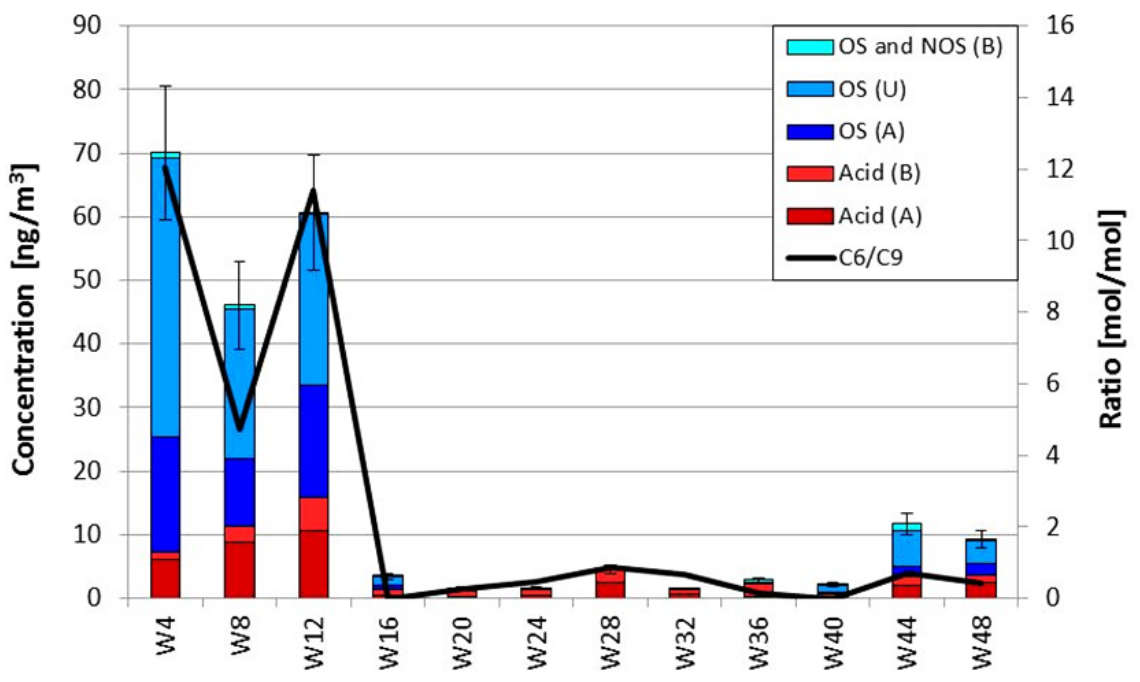

Figure 4. Variation in total air concentration $\left(\mathrm{ng} \mathrm{m}^{-3}\right)$ of observed acids and organosulfates from anthropogenic (A), biogenic (B) and unknown (U) precursors every fourth week of 2010 at Station Nord. W4 corresponds to January, W8 to February, W12 to March and so on. The secondary axis shows the molar ratio of adipic acid $\left(\mathrm{C}_{6}\right)$ to azelaic acid $\left(\mathrm{C}_{9}\right)$, estimating the anthropogenic to biogenic influence. The error bars show the estimated error of $15 \%$.

(January-March) and $2.2( \pm 1) \mathrm{ng} \mathrm{m}^{-3}$ from weeks 16 to 48 (April-December).

Elevated concentrations of organic matter $(\mathrm{OM})$ were observed at Station Nord in weeks 4,8 and 12 (JanuaryMarch), 2010, while nss-sulfate showed elevated concentrations during January and March-May (weeks 4 and 8 to 20) (Nguyen et al., 2014). Increases in the atmospheric concentration of OM, nss-sulfate and several elements of anthropogenic origin have long been used as indicators of Arctic haze (Heidam et al., 1999, 2004; Iversen and Joranger, 1985; Pacyna et al., 1985; Heidam, 1981; Barrie et al., 1981; Rahn et al., 1977) and high levels of organic acids and organosulfates thus overlap with Arctic haze at Station Nord.

In weeks 4,8 and 12 (January-March) the organosulfates and nitrooxy organosulfates accounted for $7( \pm 3) \%$ of $\mathrm{OM}$ and in addition organic acids contributed on average 2 $( \pm 0.6) \%$. Furthermore, the organosulfates contributed to 5 $( \pm 5) \%$ of water-soluble sulfate at Station Nord during these weeks.

\subsubsection{Analysis of air mass back trajectories}

Provided that accurate modelling of air mass trajectories in the Arctic is challenging due to sparse meteorological data and long distances to the source regions, backwards air mass trajectories were calculated every fourth hour during each week of aerosol sampling. The trajectories were calculated five days back in time, arriving at $10 \mathrm{~m}$ above ground level at Station Nord and the trajectories for each week were subsequently clustered to identify major source regions.

Figure 5 shows the cluster analysis of trajectories for the sampling weeks of 2010 at Station Nord. Four main clus- ter maps were identified, representing the air mass transport routes for all 12 sampling weeks. Two of the identified air mass transport routes, Nord 1 (week 4 - January) and Nord 3 (week 12 - March), showed considerable transport from the Yakutsk area and the Norilsk area, respectively. Yakutsk and Norilsk have previously been identified as anthropogenic source regions in Russia, contributing to Arctic air pollution (Nguyen et al., 2013; Heidam et al., 1999, 2004; Christensen, 1997; Ottar, 1989; Pacyna et al., 1985), which could account for the high concentrations of organosulfates and anthropogenic acids observed in weeks 4 and 12 (January and March).

Nord 2 (weeks 8 (February), 24 (June) and 44 and 48 (November-December)) represents air mass transport routes, where some of the back trajectories arrived from the coastal areas of Russia close to Yakutsk but not directly from any identified pollution sources. For week 8 (February) almost half $(48 \%)$ of the back trajectories originated from the coastal area of Yakutsk, which is in line with the observed lower concentration levels compared to weeks 4 (January) and 12 (March), but higher concentrations compared to the rest of the sampling period. Transport from the Russian coastal areas is also observed for weeks 24 (June), 44 (November) and 48 (December) (14-20\% of trajectories).

Back trajectories for the rest of the sampling weeks at Station Nord (represented as Nord 4 (weeks 16 (April), 20 (May) and 32-40 (August-October)) showed significant transport from the Arctic Ocean as well as the northwestern coast of Greenland and the northern coast of Canada, correlating with the observation of very low concentrations of organosulfates and organic acids. A small peak in the concentration of biogenic organic acids as well as $\mathrm{OM}$ and the 


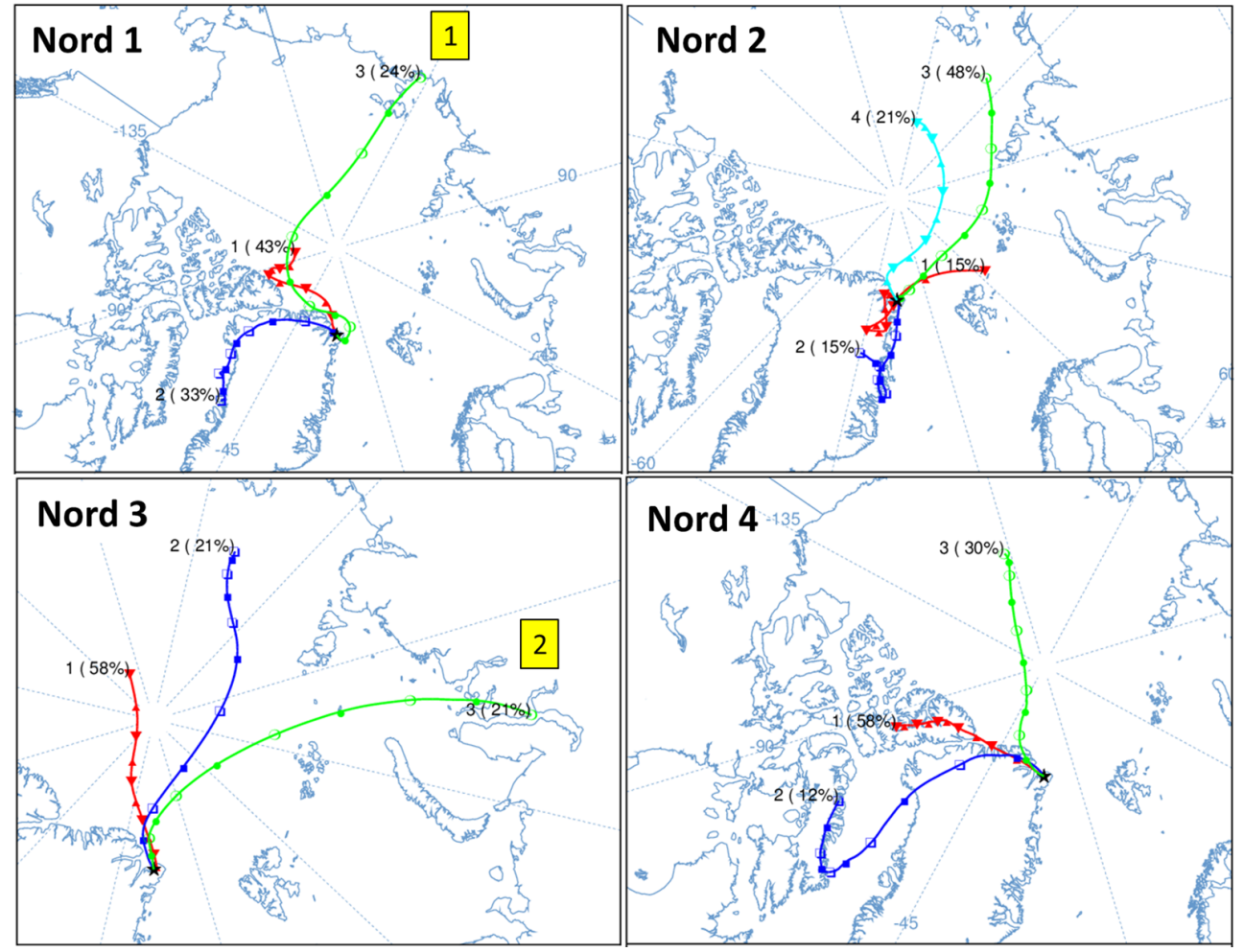

Figure 5. Five-day backward air trajectories ending at Station Nord at $10 \mathrm{~m}$ height above ground level, calculated using the HYSPLIT model. Backward air trajectories were made for every fourth hour and clustered for each sampling week of 2010 (each coloured trajectory represents a cluster mean). Sampling weeks with similar trajectory patterns are represented by one map in the following manner: Nord 1 week 4; Nord 2 weeks 8, 24, 44 and 48; Nord 3 week 12; and Nord 4 weeks 16, 20 and 32-40. The 1 marks the location of the Yakutsk area and the 2 marks the location of the Norilsk area, two anthropogenic source regions contributing to air pollution in the Arctic (Ottar, 1989; Pacyna et al., 1985).

biomass burning tracer levoglucosan (Nguyen et al., 2014) was detected for week 28 (July). Nguyen et al. (2014) suggested that during this week aerosols at Station Nord could be influenced by biomass burning aerosols; however the source region was unclear.

\subsubsection{Anthropogenic and biogenic contribution to SOA at Station Nord}

Of the SOA species analysed in this study, unknown organosulfates contributed the most to Arctic haze aerosols followed by the identified anthropogenic organosulfate compounds, anthropogenic acids, biogenic acids and finally the biogenic organosulfates. The small contribution of biogenic SOA compounds observed in weeks 4 (January) through 12 (March) is not surprising, since emission of monoterpenes is limited in the Arctic and the Russian source regions (see Fig. 3). Interestingly, maximum concentrations of the identified BSOA tracers were observed during the Arctic haze period and not during summer, when emissions of BVOCs are expected to be highest. This result suggests that long-range transport and inefficient removal processes during winter and spring are possibly more important factors affecting concen- trations of BSOA at Station Nord than emissions in the region during summer.

The molar ratio of $\mathrm{C}_{6}$ (azelaic acid) $/ \mathrm{C}_{9}$ (adipic acid) organic acids can be used to estimate the anthropogenic to biogenic contribution to SOA, as suggested by Ho et al. (2006). A value above 1 could indicate anthropogenic dominance, whereas a value below 1 could indicate biogenic dominance. The three samples with high concentrations of organosulfates and organic acids (weeks 4-12 (JanuaryMarch)) showed high $\mathrm{C}_{6} / \mathrm{C}_{9}$ values (5-12), supporting a strong anthropogenic contribution. During the rest of the year, the $\mathrm{C}_{6} / \mathrm{C}_{9}$ ratio was close to 1 , indicating equal contributions from anthropogenic and biogenic precursors. The drop in $\mathrm{C}_{6} / \mathrm{C}_{9}$ values between weeks 12 (March) and 16 (April) was due to a combination of a rise in the $\mathrm{C}_{9}$ concentration from $\sim 0.3 \mathrm{ng} \mathrm{m}^{-3}$ in weeks 4 to 12 (January-March) to $\sim 0.7 \mathrm{ng} \mathrm{m}^{-3}$ in weeks 16 to 48 (April-December) and a drop in the $\mathrm{C}_{6}$ concentration from $\sim 1.5 \mathrm{ng} \mathrm{m}^{-3}$ in weeks 4 to 12 (January-March) to $\sim 0.4 \mathrm{ng} \mathrm{m}^{-3}$ in weeks 16 to 48 (April-December). 


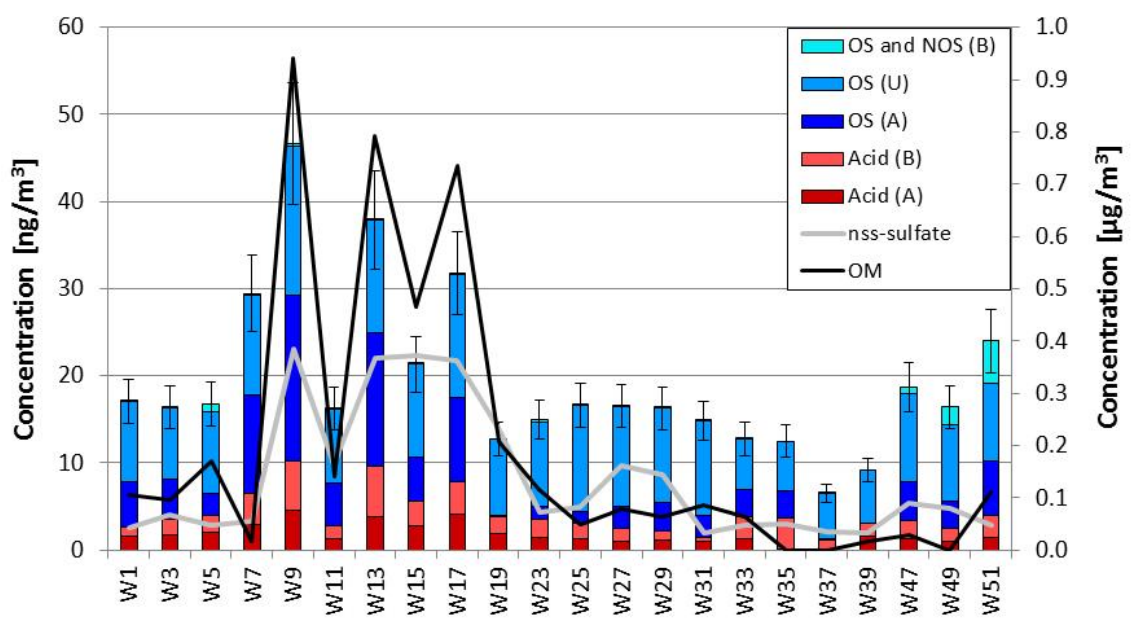

Figure 6. Variation in total air concentration $\left(\mathrm{ng} \mathrm{m}^{-3}\right)$ of observed acids and organosulfates from anthropogenic (A), biogenic (B) and unknown (U) precursors during a full annual cycle at Zeppelin Mountain, Svalbard, 2008. Approximately two samples are collected for each month, W1 and W3 from January; W5, W7 and W9 from February; W11 and W13 from March; W15 and W17 from April; W19 from May; W23 and W25 from June; W27 and W29 from July; W31, W33 and W35 from August; W37 and W39 from September; W47 from November; and W49 and W51 from December. nss-sulfate and OM $\left(\mu \mathrm{g} \mathrm{m}^{-3}\right)$ are depicted on the secondary axis. The error bars show the estimated $15 \%$ uncertainties on the concentrations.

\subsection{Zeppelin Mountain}

Figure 6 shows the annual variation in concentrations of organic acids and organosulfates at Zeppelin station in 2008. In general, the total concentration of organosulfate and organic acid species showed a quite constant concentration throughout the year with mean concentrations of $14.7( \pm 4) \mathrm{ng} \mathrm{m}^{-3}$ and $3.9( \pm 1) \mathrm{ng} \mathrm{m}^{-3}$, respectively. However, four weeks (weeks 7, 9, 13 and 17) showed a clear increase in concentrations of both organosulfates and organic acids, where the mean total concentration of organosulfates reached 27.8 $( \pm 6) \mathrm{ng} \mathrm{m}^{-3}$, whereas the mean total concentration of organic acid was $8.6( \pm 2) \mathrm{ng} \mathrm{m}^{-3}$. These four weeks occurred within late winter and early spring, coinciding with elevated levels of organic matter and nss-sulfate observed in weeks 9 , 13 and 17 (Fig. 6), and as for Station Nord, the increased levels of SOA tracers are thus confined within the Arctic haze period.

During Arctic haze the measured organosulfates contributed $4 \pm 1 \%$ to $\mathrm{OM}$ and $3.7 \pm 1 \%$ to nss-sulfate at Zeppelin Mountain, whereas during the remaining part of the year the contribution is $15 \pm 9 \%$ and $9 \pm 5 \%$ to $\mathrm{OM}$ and nss-sulfate, respectively. These results are in line with a previous study by Frossard et al. (2011), where organosulfates contributed to $6 \%$ of total sulfate and $9-11 \%$ of submicron organic aerosol mass over the Arctic Ocean close to Svalbard during spring 2008. Frossard et al. (2011) estimated the organosulfate contribution to aerosol mass and total sulfate from the organic functional group contribution, quantified using Fourier-transform infrared (FTIR) spectroscopy. Contrary to our HPLC-qTOF-MS method, the FTIR method does not provide information on the organosulfate speciation, only the presence of the functional group; hence concentration levels of individual organosulfates and variations in the organosulfate composition were not obtained.

The considerably larger contribution of organosulfates to $\mathrm{OM}$ and nss-sulfate outside the Arctic haze period, discovered in this study, is interesting and can be caused by multiple factors. One possibility is that the organic aerosols transported to Zeppelin during Arctic haze contained a smaller mass fraction of organosulfates compared to aerosols from local and subarctic regions. Even though long-range transport also occurs during summer and autumn, removal processes are thought to be more efficient, possibly resulting in local emissions and emissions from subarctic regions to gain a higher relative weight in the aerosol composition compared to long-range transport.

According to our results Arctic haze persisted further into spring at Zeppelin Mountain in 2008 than at Station Nord in 2010. It was expected that Arctic haze would also last until April at Station Nord, as was observed in other studies (Heidam et al., 2004). The short Arctic haze period at Station Nord in 2010 might be caused by either an unrepresentative sample from week 16 (April), giving a low concentration of the measured species, or by meteorological differences between the two sampling years, causing the polar air dome to contract earlier in 2010 and shortening the period of Arctic haze.

Even though the seasonal variation in organic acid and organosulfate concentrations at Station Nord and Zeppelin Mountain are very different, the concentration ranges of the observed compounds are comparable in magnitude (Table 2), Station Nord, however, experiences both the maximum and minimum summed concentration of organic acids and of 
Table 2. Concentration ranges, median concentrations and mean concentrations of the individual and summed organic acids and organosulfates observed at Station Nord and at Zeppelin Mountain. Anthropogenic compounds are marked with (A), unknown compounds with (U), biogenic compounds from fatty acids with (BF) and biogenic compounds from monoterpenes with (BM). All values are in ng $\mathrm{m}^{-3}$. BLD denotes values below detection limit.

\begin{tabular}{|c|c|c|c|c|c|c|}
\hline \multirow[t]{2}{*}[\mathrm{ng}\mathrm{m}^{-3}]{} & \multicolumn{3}{|c|}{ Station Nord } & \multicolumn{3}{|c|}{ Zeppelin Mountain } \\
\hline & range & median & mean & range & median & mean \\
\hline Adipic acid (A) & $0.13-1.96$ & 0.31 & 0.61 & $0.39-2.91$ & 1.11 & 0.77 \\
\hline Pimelic acid (A) & $0.01-0.38$ & 0.13 & 0.18 & $0.05-0.57$ & 0.20 & 0.15 \\
\hline Benzoic acid (A) & - & - & - & BDL-1.14 & 0.42 & 0.37 \\
\hline Phthalic acid (A) & $0.05-8.29$ & 0.17 & 2.22 & $0.02-1.45$ & 0.28 & 0.20 \\
\hline Suberic acid (BF) & $0.01-0.53$ & 0.12 & 0.21 & $0.07-1.68$ & 0.43 & 0.37 \\
\hline Azelaic acid (BF) & $0.10-1.43$ & 0.65 & 0.58 & $0.05-1.46$ & 0.69 & 0.70 \\
\hline Pinic acid (BM) & BDL-1.81 & 0.10 & 0.35 & $0.09-1.28$ & 0.31 & 0.24 \\
\hline Pinonic acid (BM) & $0.02-0.18$ & 0.06 & 0.06 & $0.07-0.97$ & 0.36 & 0.26 \\
\hline Terpenylic acid (BM) & $0.05-1.83$ & 0.14 & 0.32 & $0.07-2.88$ & 0.40 & 0.21 \\
\hline DTAA $(B M)^{1}$ & $0.01-0.05$ & 0.02 & 0.03 & $0.03-0.16$ & 0.09 & 0.08 \\
\hline $\operatorname{MBTCA}(\mathrm{BM})^{2}$ & $0.02-1.05$ & 0.14 & 0.25 & $0.09-0.67$ & 0.28 & 0.27 \\
\hline Sum organic acids & $0.39-17.50$ & 1.83 & 4.82 & $0.93-15.19$ & 4.57 & 3.63 \\
\hline OS $140(\mathrm{~A})$ & $0.01-2.08$ & 0.10 & 0.38 & $0.03-1.62$ & 0.36 & 0.13 \\
\hline OS $154(\mathrm{~A})$ & BDL-2.72 & 0.11 & 0.54 & $1.27-9.56$ & 3.36 & 3.09 \\
\hline OS $168(\mathrm{~A})$ & $0.01-5.44$ & 0.13 & 1.31 & $0.02-5.47$ & 0.97 & 0.52 \\
\hline OS $180(\mathrm{U})$ & $0.01-1.81$ & 0.05 & 0.47 & $0.01-2.06$ & 0.42 & 0.27 \\
\hline OS $182(\mathrm{~A})$ & $0.16-11.14$ & 1.04 & 3.72 & $0.03-8.54$ & 1.78 & 0.82 \\
\hline OS 196a (U) & BDL-1.64 & 0.35 & 0.58 & $0.32-5.68$ & 2.38 & 2.14 \\
\hline OS 196b (U) & $0.04-17.55$ & 1.59 & 5.26 & - & - & - \\
\hline OS $208(\mathrm{U})$ & - & - & - & $0.04-4.46$ & 0.68 & 0.32 \\
\hline OS $210(\mathrm{U})$ & $0.01-13.99$ & 0.38 & 2.89 & $4.13-11.06$ & 6.26 & 5.80 \\
\hline OS 224 (U) & $0.01-9.39$ & 0.26 & 1.79 & $0.01-5.34$ & 0.73 & 0.13 \\
\hline OS $250(\mathrm{BM})$ & BDL-0.99 & 0.07 & 0.18 & $0.01-487$ & 0.60 & 0.08 \\
\hline OS $280(\mathrm{BM})$ & BDL-0.69 & 0.05 & 0.19 & $0.01-0.16$ & 0.04 & 0.03 \\
\hline NOS 295 (BM) & BDL-0.18 & 0.03 & 0.06 & BDL-0.05 & 0.03 & 0.03 \\
\hline Sum organosulfates & $0.25-67.63$ & 4.15 & 17.42 & $5.88-58.87$ & 17.61 & 13.36 \\
\hline
\end{tabular}

organosulfates. In general the organosulfates are more abundant at both stations compared to the organic acids - OS 154, OS 184, OS 196b and OS 210 being most abundant at Zeppelin Mountain and OS 182 and OS 196b being most abundant at Station Nord. The most pronounced organic acids are azelaic acid and adipic acid. The concentrations of the individual organic acids are in the range of previous studies in the Arctic and in Mainz, Germany, but approximately a magnitude lower than concentrations measured in Tokyo and in Chinese cities (Zhang et al., 2010; Ho et al., 2007; Kawamura and Yasui, 2005; Kawamura et al., 1996).

\subsubsection{Connection between source region and organosulfate complexity at Zeppelin Mountain}

In Fig. 7 the relative composition of the organosulfate species observed at Zeppelin Mountain in 2008 is shown. A clear distinction between the samples was recognized: the organosulfate composition showed increased complexity from weeks
1 to 15 and from week 47 to week 51 , compared to week 17 to week 39. Hence, during the winter-spring period, when transport from the mid-latitudes is most pronounced and aerosol sinks are least active, the number of different organosulfates contributing to aerosol particles was much higher (7-10 species) than during the summer and autumn (2-4 species). The increased complexity is due to three additional organosulfates identified as anthropogenic (OS 140, OS 168 and OS 182) and two unknown (OS 180 and OS 224).

Based on HYSPLIT trajectories (see Fig. 8), it was recognized that the increased number of identified organosulfates correlated with air masses transported from Russia or the coastal area of Russia in all studied weeks during the Arctic haze period with the exception of W5 and W7. In contrast, during the summer and autumn periods (weeks 17-39), air masses primarily originated from locations within the high Arctic, Greenland and the coastal areas of the Scandinavian countries. Russian areas such as Norilsk and Yakutsk have long been known as source areas of atmospheric pollution 


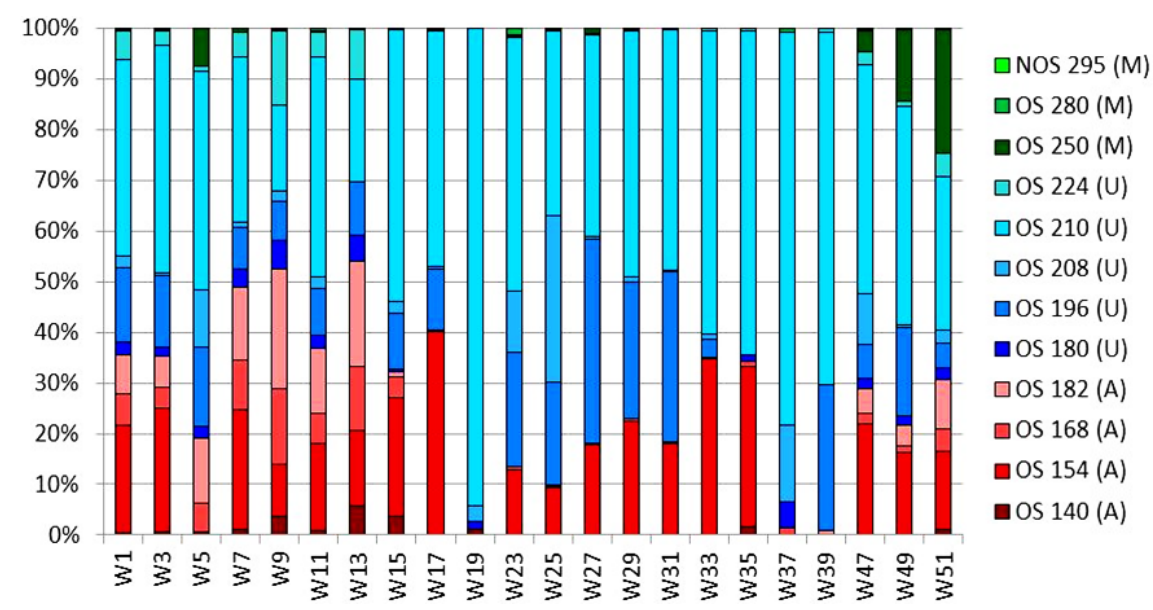

Figure 7. Relative composition of organosulfates from monoterpene (M), anthropogenic (A), and unknown (U) precursors observed at Zeppelin Mountain, Svalbard, 2008. Approximately two samples are collected for each month, W1 and W3 from January; W5, W7 and W9 from February; W11 and W13 from March; W15 and W17 from April; W19 from May, W23 and W25 from June; W27 and W29 from July; W31, W33 and W35 from August; W37 and W39 from September; W47 from November; and W49 and W51 from December.

due to metal smelting and coal combustion (Hirdman et al., 2010; Ottar, 1989; Pacyna et al., 1985). Our observations of a higher organosulfate complexity when air was transported from these areas compared to less polluted regions, such as ocean regions, Greenland and Scandinavian coastal areas, implies a connection between organosulfate complexity and the level of air pollution. This is in line with chamber studies, pointing out the importance of acidic sulfate aerosols for organosulfate formation (Gómez-Gonzàlez et al., 2008; Iinuma et al., 2007).

One organosulfate (OS 210) was found in relatively high concentrations $\left(>4 \mathrm{ng} \mathrm{m}^{-3}\right.$ ) in all the samples from Svalbard, possibly indicating a regional source. To our knowledge OS 210 has not been reported before in either field investigations or smog chamber studies.

The correlations between the observed organosulfates were investigated. A high correlation coefficient $\left(R^{2}>0.95\right.$, $n>13$ ) was found between OS 168 , OS 180 , OS 182 and OS 224, implying common precursors or common source areas. As the source areas (identified from the back trajectories) changed between the samples, where OS 168, OS 180, OS 182 and OS 224 are observed, a common precursor is more likely. As mentioned in Sect. 3.1, methacrolein and 2-methylglyceric acid, a photooxidation product of methacrolein (Zhang et al., 2012), are suggested precursors of OS 168 and 182, respectively. Methacrolein or an oxidation product of methacrolein could be precursors of OS 180 and OS 224. Correlations between OS compounds were also computed for the Station Nord samples, showing a good correlation between the same four organosulfates, but with only few available data points $(n<6)$, no final conclusions could be drawn.

Regarding the organosulfate concentration levels at Zeppelin Mountain (Fig. 6), the stable concentration observed during most weeks (weeks 1 to 5, weeks 11 and 15, and weeks 19 to 51) remains unexplained. The specific organosulfate composition showed a distinct variation during the annual cycle (Fig. 7), suggesting changes in sources and emissions, which were supported by the trajectory analysis as well as the emission maps (Figs. 2 and 3). The stable concentration level may possibly be caused by large-scale recirculation of air masses within the Arctic area.

\section{Conclusions}

At the two Arctic sites investigated in this study (Station Nord and Zeppelin Mountain), organosulfates and organic acids were detected throughout the year, with observed maximum concentrations overlapping with the Arctic haze period. Organic acids and organosulfates from anthropogenic precursors dominated the SOA collected at the two sites, with biogenic organosulfates being almost negligible throughout the year. Both the anthropogenic and the biogenic species reached their maximum concentrations during the Arctic haze period, suggesting that long-range transport is the main source of SOA in the Arctic. The transport pattern and source regions of the sampled aerosols were investigated by modelling backwards air mass trajectories using the HYSPLIT model. The model results indicated Russian areas, especially Norilsk and Yakutsk, as potential source regions of Arctic haze and organosulfates at both sites. Furthermore, at Zeppelin station it was observed that the complexity (i.e. number) of organosulfate species was highly dependent on source area. When Russian areas were involved as source regions, the organosulfates showed a $100 \%$ increase in complexity compared to source areas such as Greenland, coastal areas of Scandinavia and the Arctic Ocean. 


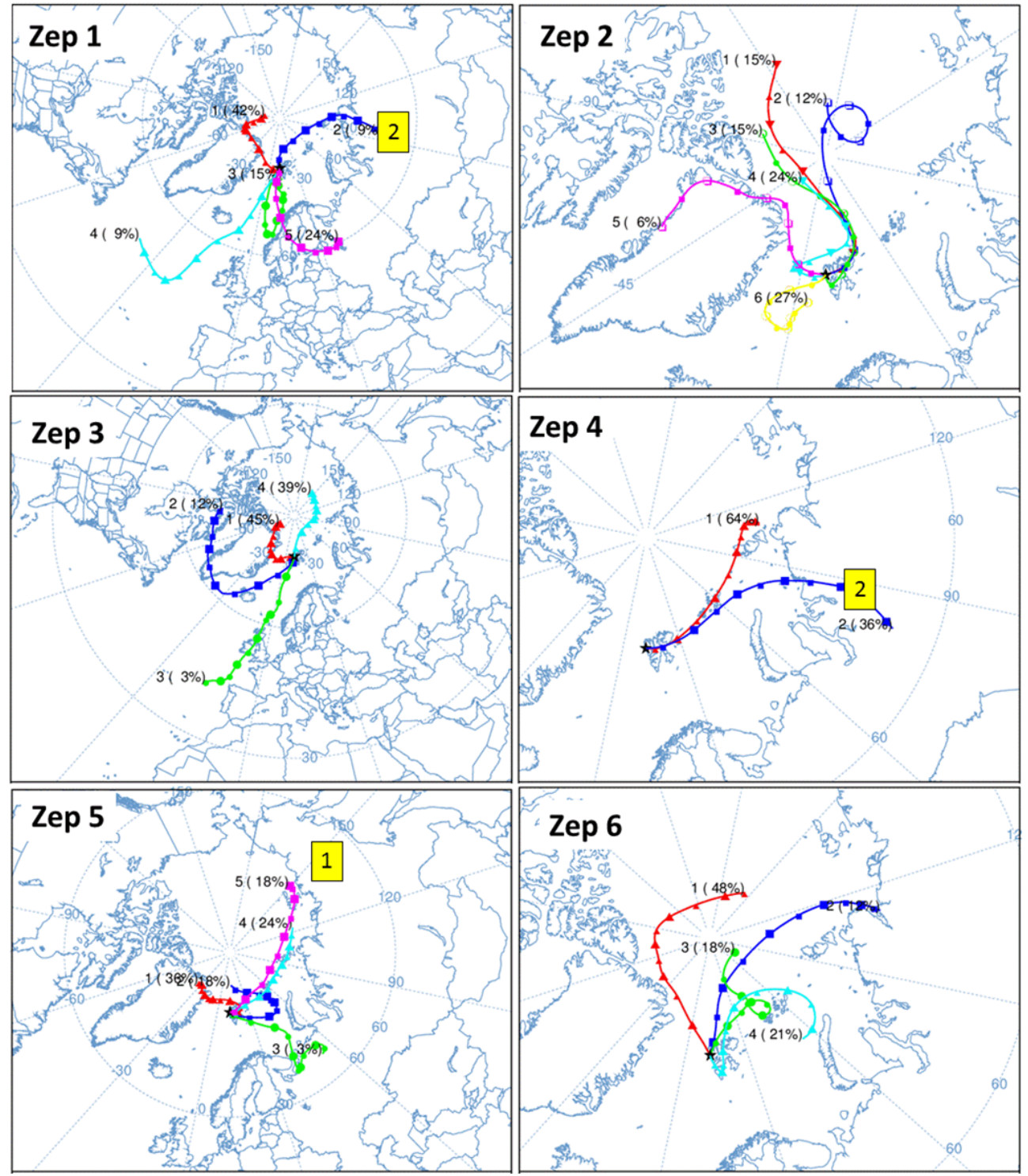

Figure 8. Five-day backwards air mass trajectories ending at Zeppelin Mountain at $10 \mathrm{~m}$ height above ground level, calculated using the HYSPLIT model. Backwards air mass trajectories were made for every fourth hour and clustered for each sampling week of 2008 (each coloured trajectory represents a cluster mean). Sampling weeks with similar trajectory patterns are represented by one map in the following manner: Zep1 weeks 1 and 3; Zep 2 weeks 5, 19-35 and 39; Zep 3 weeks 7 and 37; Zep 4 week 9; Zep 5 weeks 11 and 15; and Zep 6 weeks 13, 17 and 47-51. The 1 marks the location of the Yakutsk area and the 2 marks the location of the Norilsk area, two anthropogenic sources contributing to air pollution in the Arctic (Ottar, 1989; Pacyna et al., 1985).

Six organosulfates (OS 180, OS 196a, OS 196b, OS 208, OS 210 and OS 224), which to our knowledge have not been reported before, were observed at both sites. OS 180 and OS 224 correlated perfectly with OS 168 and 182, which have been suggested to form from methacrolein, indicating that methacrolein could be the precursor of these two organosulfates as well. Based on this study it has not been possible to deduce structures or to account for precursors for the other four organosulfates. It is, however, suggested that the precursors are of anthropogenic or marine origin as the organosulfate formation from major terrestrial BVOCs, isoprene and monoterpenes, have been studied thoroughly in smog chamber studies.

Despite the knowledge obtained in the present paper, there is still a lack of knowledge concerning time tends, source regions, atmospheric formations and sinks of organosulfates in the Arctic, and therefore further studies are needed. 


\section{The Supplement related to this article is available online at doi:10.5194/acp-14-7807-2014-supplement.}

Acknowledgements. This research was supported by NordForsk (Nordic Council of Ministers) through the Nordic Centre of Excellence Cryosphere-Atmosphere Interactions in a Changing Arctic Climate (CRAICC), the VILLUM Foundation, the Swedish Environmental Protection Agency (Naturvårdsverket), Swedish Research Council (Vetenskapsrådet) within the framework of the CLIMSLIP (CLimate Impact of Short-Lived Pollutants in the polar region) project and the Danish Environmental Protection Agency with means from the MIKA/DANCEA funds for Environmental Support to the Arctic Region. The findings and conclusions presented here do not necessarily reflect the views of the Danish Environmental Protection Agency.

The authors acknowledge Tabea Hennig and Birgitta Noone from ITM, Stockholm University, and the Norwegian Polar Institute (NPI) for their work with maintenance of the measurement equipment at Zeppelin station used in this study and also the Norwegian Institute for Air Research (NILU) for providing measurements of nss-sulfate at Svalbard. Furthermore the Royal Danish Air Force is acknowledged for providing transport to Station Nord, and the staff at Station Nord is especially acknowledged for excellent support.

Edited by: V.-M. Kerminen

\section{References}

ACIA: Arctic Climate Impact Assessment, Overview Report, Cambridge Univ. Press, Cambridge, 140 pp., 2004.

Albrecht, B. A.: Aerosols, Cloud Microphysics, and Fractional Cloudiness, Science, 245, 1227-1230, doi:10.1126/science.245.4923.1227, 1989.

Austin, J. F.: The Blocking of Middle Latitude Westerly Winds by Planetary-Waves, Q. J. Roy. Meteor. Soc., 106, 327-350, doi:10.1002/qj.49710644807, 1980.

Barrie, L. A., Hoff, R. M., and Daggupaty, S. M.: The Influence of Mid-Latitudinal Pollution Sources on Haze in the Canadian Arctic, Atmos. Environ., 15, 1407-1419, doi:10.1016/00046981(81)90347-4, 1981.

Beine, H. J., Argentini, S., Maurizi, A., Mastrantonio, G., and Viola, A.: The local wind field at Ny-Ålesund and the Zeppelin mountain at Svalbard, Meteorol. Atmos. Phys., 78, 107-113, doi:10.1007/s007030170009, 2001.

Bennartz, R., Shupe, M. D., Turner, D. D., Walden, V. P., Steffen, K., Cox, C. J., Kulie, M. S., Miller, N. B., and Pettersen, C.: July 2012 Greenland melt extent enhanced by low-level liquid clouds, Nature, 496, 83-86, doi:10.1038/Nature12002, 2013.

Biesenthal, T. A. and Shepson, P. B.: Observations of anthropogenic inputs of the isoprene oxidation products methyl vinyl ketone and methacrolein to the atmosphere, Geophys. Res. Lett., 24, 13751378, doi:10.1029/97GL01337, 1997.

Brandt, J., Silver, J. D., Frohn, L. M., Geels, C., Gross, A., Hansen, A. B., Hansen, K. M., Hedegaard, G. B., Skjoth, C. A., Villadsen, H., Zare, A., and Christensen, J. H.: An integrated model study for Europe and North America using the Danish Eulerian Hemispheric Model with focus on interconti- nental transport of air pollution, Atmos. Environ., 53, 156-176, doi:10.1016/j.atmosenv.2012.01.011, 2012.

Bunce, N. J., Liu, L., Zhu, J., and Lane, D. A.: Reaction of naphthalene and its derivatives with hydroxyl radicals in the gas phase, Environ. Sci. Technol., 31, 2252-2259, doi:10.1021/Es960813g, 1997.

Cavalli, F., Viana, M., Yttri, K. E., Genberg, J., and Putaud, J.-P.: Toward a standardised thermal-optical protocol for measuring atmospheric organic and elemental carbon: the EUSAAR protocol, Atmos. Meas. Tech., 3, 79-89, doi:10.5194/amt-3-79-2010, 2010.

Chan, M. N., Surratt, J. D., Chan, A. W. H., Schilling, K., Offenberg, J. H., Lewandowski, M., Edney, E. O., Kleindienst, T. E., Jaoui, M., Edgerton, E. S., Tanner, R. L., Shaw, S. L., Zheng, M., Knipping, E. M., and Seinfeld, J. H.: Influence of aerosol acidity on the chemical composition of secondary organic aerosol from ?-caryophyllene, Atmos. Chem. Phys., 11, 1735-1751, doi:10.5194/acp-11-1735-2011, 2011.

Charlson, R. J., Schwartz, S. E., Hales, J. M., Cess, R. D., Coakley, J. A., Hansen, J. E., and Hofmann, D. J: Climate Forcing by Anthropogenic Aerosols, Science, 255, 423-430, doi:10.1126/science.255.5043.423, 1992.

Christensen, J. H.: The Danish Eulerian hemispheric model - A three-dimensional air pollution model used for the Arctic, Atmos. Environ., 31, 4169-4191, doi:10.1016/S13522310(97)00264-1, 1997.

Claeys, M., Iinuma, Y., Szmigielski, R., Surratt, J. D., Blockhuys, F., Van Alsenoy, C., Böge, O., Sierau, B., Gomez-Gonzalez, Y., Vermeylen, R., Van der Veken, P., Shahgholi, M., Chan, A. W. H., Herrmann, H., Seinfeld, J. H., and Maenhaut, W.: Terpenylic Acid and Related Compounds from the Oxidation of alpha-Pinene: Implications for New Particle Formation and Growth above Forests, Environ. Sci. Technol., 43, 6976-6982, doi:10.1021/Es9007596, 2009.

Draxler, R. R. and Hess, G. D.: An overview of the HYSPLIT_4 modelling system for trajectories, dispersion and deposition, Aust. Meteorol. Mag., 47, 295-308, 1998.

Fenger, M., Sørensen, L. L., Kristensen, K., Jensen, B., Nguyen, Q. T., Nøjgaard, J. K., Massling, A., Skov, H., Becker, T., and Glasius, M.: Sources of anions in aerosols in northeast Greenland during late winter, Atmos. Chem. Phys., 13, 1569-1578, doi:10.5194/acp-13-1569-2013, 2013.

Frossard, A. A., Shaw, P. M., Russell, L. M., Kroll, J. H., Canagaratna, M. R., Worsnop, D. R., Quinn, P. K., and Bates, T. S.: Springtime Arctic haze contributions of submicron organic particles from European and Asian combustion sources, J. Geophys. Res.-Atmos., 116, D05205, doi:10.1029/2010jd015178, 2011.

Fu, P. Q., Kawamura, K., Chen, J., and Barrie, L. A.: Isoprene, Monoterpene, and Sesquiterpene Oxidation Products in the High Arctic Aerosols during Late Winter to Early Summer, Environ. Sci. Technol., 43, 4022-4028, doi:10.1021/Es803669a, 2009.

Glasius, M., Lahaniati, M., Calogirou, A., Di Bella, D., Jensen, N. R., Hjorth, J., Kotzias, D., and Larsen, B. R.: Carboxylic acids in secondary aerosols from oxidation of cyclic monoterpenes by ozone, Environ. Sci. Technol., 34, 1001-1010, doi:10.1021/Es990445r, 2000.

Gómez-Gonzàlez, Y., Surratt, J. D., Cuyckens, F., Szmigielski, R., Vermeylen, R., Jaoui, M., Lewandowski, M., Offenberg, J. H., Kleindienst, T. E., Edney, E. O., Blockhuys, F., Van Alsenoy, C., 
Maenhaut, W., and Claeys, M.: Characterization of organosulfates from the photooxidation of isoprene and unsaturated fatty acids in ambient aerosol using liquid chromatography/(-) electrospray ionization mass spectrometry, J. Mass Spectrom., 43, 371-382, doi:10.1002/Jms.1329, 2008.

Guenther, A.: Seasonal and spatial variations in natural volatile organic compound emissions, Ecol. Appl., 7, 3445, doi:10.2307/2269405, 1997.

Guenther, A., Karl, T., Harley, P., Wiedinmyer, C., Palmer, P. I., and Geron, C.: Estimates of global terrestrial isoprene emissions using MEGAN (Model of Emissions of Gases and Aerosols from Nature), Atmos. Chem. Phys., 6, 3181-3210, doi:10.5194/acp-63181-2006, 2006.

Hakola, H., Hellen, H., Tarvainen, V., Back, J., Patokoski, J., and Rinne, J.: Annual variations of atmospheric VOC concentrations in a boreal forest, Boreal Environ. Res., 14, 722-730, 2009.

Hallquist, M., Wenger, J. C., Baltensperger, U., Rudich, Y., Simpson, D., Claeys, M., Dommen, J., Donahue, N. M., George, C., Goldstein, A. H., Hamilton, J. F., Herrmann, H., Hoffmann, T., Iinuma, Y., Jang, M., Jenkin, M. E., Jimenez, J. L., Kiendler-Scharr, A., Maenhaut, W., McFiggans, G., Mentel, Th. F., Monod, A., Prévôt, A. S. H., Seinfeld, J. H., Surratt, J. D., Szmigielski, R., and Wildt, J.: The formation, properties and impact of secondary organic aerosol: current and emerging issues, Atmos. Chem. Phys., 9, 5155-5236, doi:10.5194/acp-9-51552009, 2009.

Hatakeyama, S., Ohno, M., Weng, J. H., Takagi, H., and Akimoto, H.: Mechanism for the Formation of Gaseous and Particulate Products from Ozone-Cycloalkene Reactions in Air, Environ. Sci. Technol., 21, 52-57, doi:10.1021/Es00155a005, 1987.

Heidam, N. Z.: On the Origin of the Arctic Aerosol - a Statistical Approach, Atmos. Environ., 15, 1421-1427, doi:10.1016/00046981(81)90348-6, 1981.

Heidam, N. Z., Wahlin, P., and Christensen, J. H.: Tropospheric gases and aerosols in northeast Greenland, J. Atmos. Sci., 56, 261-278, doi:10.1175/15200469(1999)056<0261:Tgaain>2.0.CO;2, 1999.

Heidam, N. Z., Christensen, J., Wahlin, P., and Skov, H.: Arctic atmospheric contaminants in NE Greenland: levels, variations, origins, transport, transformations and trends 1990-2001, Sci. Total Environ., 331, 5-28, doi:10.1016/j.scitotenv.2004.03.033, 2004.

Heintzenberg, J. and Larssen, $\mathrm{S} .: \mathrm{SO}_{2}$ and $\mathrm{SO}_{4}^{=}$in the Arctic - Interpretation of Observations at 3 Norwegian Arctic-Subarctic Stations, Chem. Phys. Meteorol., 35, 255-265, 1983.

Hirdman, D., Sodemann, H., Eckhardt, S., Burkhart, J. F., Jefferson, A., Mefford, T., Quinn, P. K., Sharma, S., Ström, J., and Stohl, A.: Source identification of short-lived air pollutants in the Arctic using statistical analysis of measurement data and particle dispersion model output, Atmos. Chem. Phys., 10, 669-693, doi:10.5194/acp-10-669-2010, 2010.

Ho, K. F., Lee, S. C., Cao, J. J., Kawamura, K., Watanabe, T., Cheng, Y., and Chow, J. C.: Dicarboxylic acids, ketocarboxylic acids and dicarbonyls in the urban roadside area of Hong Kong, Atmos. Environ., 40, 3030-3040, doi:10.1016/j.atmosenv.2005.11.069, 2006.

Ho, K. F., Cao, J. J., Lee, S. C., Kawamura, K., Zhang, R. J., Chow, J. C., and Watson, J. G.: Dicarboxylic acids, ketocarboxylic acids, and dicarbonyls in the urban atmosphere of China, J. Geo- phys. Res.-Atmos., 112, D22S27, doi:10.1029/2006jd008011, 2007.

Hoyle, C. R., Boy, M., Donahue, N. M., Fry, J. L., Glasius, M., Guenther, A., Hallar, A. G., Huff Hartz, K., Petters, M. D., Petäjä, T., Rosenoern, T., and Sullivan, A. P.: A review of the anthropogenic influence on biogenic secondary organic aerosol, Atmos. Chem. Phys., 11, 321-343, doi:10.5194/acp-11-321-2011, 2011.

Hudson, S. R.: Estimating the global radiative impact of the sea ice-albedo feedback in the Arctic, J. Geophys. Res.-Atmos., 116, D16102, doi:10.1029/2011jd015804, 2011.

Iinuma, Y., Müller, C., Berndt, T., Böge, O., Claeys, M., and Herrmann, H.: Evidence for the existence of organosulfates from beta-pinene ozonolysis in ambient secondary organic aerosol, Environ. Sci. Technol., 41, 6678-6683, doi:10.1021/Es070938t, 2007.

Iinuma, Y., Böge, O., Kahnt, A., and Herrmann, H.: Laboratory chamber studies on the formation of organosulfates from reactive uptake of monoterpene oxides, Phys. Chem. Chem. Phys., 11, 7985-7997, doi:10.1039/B904025k, 2009.

Intrieri, J. M., Shupe, M. D., Uttal, T., and McCarty, B. J.: An annual cycle of Arctic cloud characteristics observed by radar and lidar at SHEBA, J. Geophys. Res.-Oceans, 107, 8030, doi:10.1029/2000jc000423, 2002.

IPCC: Summary for Policymakers. In: Climate Change 2013: The Physical Science Basis, Contribution of Working Group I to the Fifth Assessment Report of the Intergovernmental Panel on Climate Change, edited by: Stocker, T. F., Qin, D., Plattner, G.-K., Tignor, M., Allen, S. K., Boschung, J., Nauels, A., Xia, Y., Bex, V., and Midgley, P. M., Cambridge University Press, Cambridge, United Kingdom and New York, NY, USA, 3-28, 2013.

Iversen, T. and Joranger, E.: Arctic Air-Pollution and LargeScale Atmospheric Flows, Atmos. Environ., 19, 2099-2108, doi:10.1016/0004-6981(85)90117-9, 1985.

Kahnt, A., Behrouzi, S., Vermeylen, R., Safi Shalamzari, M., Vercauteren, J., Roekens, E., Claeys, M., and Maenhaut, W.: Oneyear study of nitro-organic compounds and their relation to wood burning in $\mathrm{PM}_{10}$ aerosol from a rural site in Belgium, Atmos. Environ., 81, 561-568, doi:10.1016/j.atmosenv.2013.09.041., 2013.

Kawamura, K. and Gagosian, R. B.: Implications of OmegaOxocarboxylic Acids in the Remote Marine Atmosphere for Photooxidation of Unsaturated Fatty-Acids, Nature, 325, 330-332, doi:10.1038/325330a0, 1987.

Kawamura, K. and Yasui, O.: Diurnal changes in the distribution of dicarboxylic acids, ketocarboxylic acids and dicarbonyls in the urban Tokyo atmosphere, Atmos. Environ., 39, 1945-1960, doi:10.1016/j.atmosenv.2004.12.014, 2005.

Kawamura, K., Kasukabe, H., and Barrie, L. A.: Source and reaction pathways of dicarboxylic acids, ketoacids and dicarbonyls in arctic aerosols: One year of observations, Atmos. Environ., 30, 1709-1722, doi:10.1016/1352-2310(95)00395-9, 1996.

Kawamura, K., Imai, Y., and Barrie, L. A.: Photochemical production and loss of organic acids in high Arctic aerosols during longrange transport and polar sunrise ozone depletion events, Atmos Environ., 39, 599-614, doi:10.1016/j.atmosenv.2004.10.020, 2005.

Kawamura, K., Okuzawa, K., Aggarwal, S. G., Irie, H., Kanaya, Y., and Wang, Z.: Determination of gaseous and particulate carbonyls (glycolaldehyde, hydroxyacetone, glyoxal, methylglyoxal, nonanal and decanal) in the atmosphere at Mt. Tai, At- 
mos. Chem. Phys., 13, 5369-5380, doi:10.5194/acp-13-53692013, 2013.

Krecl, P., Strom, J., and Johansson, C.: Carbon content of atmospheric aerosols in a residential area during the wood combustion season in Sweden, Atmos. Environ., 41, 6974-6985, doi:10.1016/j.atmosenv.2007.06.025, 2007.

Kristensen, K. and Glasius, M.: Organosulfates and oxidation products from biogenic hydrocarbons in fine aerosols from a forest in North West Europe during spring, Atmos. Environ., 45, 45464556, doi:10.1016/j.atmosenv.2011.05.063, 2011.

Lin, Y. H., Zhang, Z. F., Docherty, K. S., Zhang, H. F., Budisulistiorini, S. H., et al.: Isoprene Epoxydiols as Precursors to Secondary Organic Aerosol Formation: Acid-Catalyzed Reactive Uptake Studies with Authentic Compounds, Environ. Sci. Technol., 46, 250-258, doi:10.1021/Es202554c, 2012.

Ma, Y., Willcox, T. R., Russell, A. T., and Marston, G.: Pinic and pinonic acid formation in the reaction of ozone with alpha-pinene, Chem. Commun., 2007, 1328-1330, doi:10.1039/B617130C, 2007.

Minerath, E. C. and Elrod, M. J.: Assessing the Potential for Diol and Hydroxy Sulfate Ester Formation from the Reaction of Epoxides in Tropospheric Aerosols, Environ. Sci. Technol., 43, 13861392, doi:10.1021/Es8029076, 2009.

Mochida, M., Kawabata, A., Kawamura, K., Hatsushika, H., and Yamazaki, K.: Seasonal variation and origins of dicarboxylic acids in the marine atmosphere over the western North Pacific, J. Geophys. Res.-Atmos., 108, 4193, doi:10.1029/2002JD002355, 2003.

Myriokefalitakis, S., Vrekoussis, M., Tsigaridis, K., Wittrock, F., Richter, A., Brühl, C., Volkamer, R., Burrows, J. P., and Kanakidou, M.: The influence of natural and anthropogenic secondary sources on the glyoxal global distribution, Atmos. Chem. Phys., 8, 4965-4981, doi:10.5194/acp-8-4965-2008, 2008.

Lin, Y. H., Zhang, Z. F., Docherty, K. S., Zhang, H. F., Budisulistiorini, S. H., Rubitschun, C. L., Shaw, S. L., Knipping, E. M., Edgerton, E. S., Kleindienst, T. E., Gold, A., and Surratt, J. D.: Characterization of humic-like substances in Arctic aerosols, J. Geophys. Res., 46, 250-258, doi:10.1021/Es202554c, 2013.

Nguyen, Q. T., Skov, H., Sørensen, L. L., Jensen, B. J., Grube, A. G., Massling, A., Glasius, M., and Nøjgaard, J. K.: Source apportionment of particles at Station Nord, North East Greenland during 2008-2010 using COPREM and PMF analysis, Atmos. Chem. Phys., 13, 35-49, doi:10.5194/acp-13-35-2013, 2013.

Nguyen, Q. T., Kristensen, T. B., Hansen, A. M. K., Skov, H., Bossi, R., Massling, A., Sørensen, L. L., Bilde, M., Glasius, M., and Nøjgaard, J. K.: Characterization of humic-like substances in Arctic aerosols, J. Geophys. Res. Atmos., 119, 5011-5027, doi:10.1002/2013jd020144, 2014.

Ottar, B.: Arctic Air-Pollution - a Norwegian Perspective, Atmos. Environ., 23, 2349-2356, doi:10.1016/0004-6981(89)90248-5, 1989.

Pacyna, J. M., Ottar, B., Tomza, U., and Maenhaut, W.: Long-Range Transport of Trace-Elements to Ny-Ålesund, Spitsbergen, Atmos. Environ., 19, 857-865, doi:10.1016/0004-6981(85)902318, 1985.

Rahn, K. A.: Relative Importances of North-America and Eurasia as Sources of Arctic Aerosol, Atmos. Environ., 15, 1447-1455, doi:10.1016/0004-6981(81)90351-6, 1981.
Rahn, K. A., Borys, R. D., and Shaw, G. E.: Asian Source of Arctic Haze Bands, Nature, 268, 713-715, doi:10.1038/268713a0, 1977.

Rankin, A. M., Wolff, E. W., and Martin, S.: Frost flowers: Implications for tropospheric chemistry and ice core interpretation, J. Geophys. Res.-Atmos., 107, 4683, doi:10.1029/2002JD002492, 2002.

Rybka, A., Kolinski, R., Kowalski, J., Szmigielski, R., Domagala, S., Wozniak, K., Wieckowska, A., Bilewicz, R., and Korybut-Daszkiewicz, B.: Tuning the properties of neutral tetraazamacrocyclic complexes of copper(II) and nickel(II) for use as host-guest compounds with bismacrocyclic transition metal cations, Eur. J. Inorg. Chem., 2007, 172-185, doi:10.1002/ejic.200600744, 2007.

Sakulyanontvittaya, T., Duhl, T., Wiedinmyer, C., Helmig, D., Matsunaga, S., Potosnak, M., Milford, J., and Guenther, A.: Monoterpene and sesquiterpene emission estimates for the United States, Environ. Sci. Technol., 42, 1623-1629, doi:10.1021/Es702274e, 2008.

Sciare, J., Bardouki, H., Moulin, C., and Mihalopoulos, N.: Aerosol sources and their contribution to the chemical composition of aerosols in the Eastern Mediterranean Sea during summertime, Atmos. Chem. Phys., 3, 291-302, doi:10.5194/acp-3-291-2003, 2003.

Shaw, G. E.: Eddy Diffusion Transport of Arctic Pollution from the Mid-Latitudes - a Preliminary Model, Atmos. Environ., 15, 1483-1490, doi:10.1016/0004-6981(81)90356-5, 1981.

Shaw, G. E.: Evidence for a Central Eurasian Source Area of Arctic Haze in Alaska, Nature, 299, 815-818, doi:10.1038/299815a0, 1982.

Shaw, G. E.: The arctic haze phenomenon, B. Am. Meteorol. Soc., 76, 2403-2413, doi:10.1175/15200477(1995)076<2403:Tahp>2.0.CO;2, 1995.

Shupe, M. D. and Intrieri, J. M.: Cloud radiative forcing of the Arctic surface: The influence of cloud properties, surface albedo, and solar zenith angle, J. Climate, 17, 616-628, doi:10.1175/15200442(2004)017<0616:Crfota>2.0.CO;2, 2004.

Skov, H., Christensen, J. H., Goodsite, M. E., Heidam, N. Z., Jensen, B., Wahlin, P., and Geernaert, G.:: Fate of elemental mercury in the arctic during atmospheric mercury depletion episodes and the load of atmospheric mercury to the arctic, Environ. Sci. Technol., 38, 2373-2382, doi:10.1021/Es030080h, 2004.

Solgaard, P., Aarkrog, A., Fenger, J., Flyger, H., and Graabaek, A. M.: Lead in Danish Food-Stuffs - Evidence of Decreasing Concentrations, Dan. Med. Bull., 26, 179-182, 1979.

Stohl, A.: Characteristics of atmospheric transport into the Arctic troposphere, J. Geophys. Res.-Atmos., 111, D11306, doi:10.1029/2005jd006888, 2006.

Stohl, A., Berg, T., Burkhart, J. F., Fjae'raa, A. M., Forster, C., Herber, A., Hov, Ø., Lunder, C., McMillan, W. W., Oltmans, S., Shiobara, M., Simpson, D., Solberg, S., Stebel, K., Ström, J., Tørseth, K., Treffeisen, R., Virkkunen, K., and Yttri, K. E.: Arctic smoke - record high air pollution levels in the European Arctic due to agricultural fires in Eastern Europe in spring 2006, Atmos. Chem. Phys., 7, 511-534, doi:10.5194/acp-7-511-2007, 2007.

Stone, E. A., Yang, L. M., Yu, L. Y. E., and Rupakheti, M.: Characterization of organosulfates in atmospheric aerosols at Four Asian locations, Atmos. Environ., 47, 323-329, doi:10.1016/j.atmosenv.2011.10.058, 2012. 
Surratt, J. D., Kroll, J. H., Kleindienst, T. E., Edney, E. O., Claeys, M., Sorooshian, A., Ng, N. L., Offenberg, J. H., Lewandowski, M., Jaoui, M., Flagan, R. C., and Seinfeld, J. H.: Evidence for organosulfates in secondary organic aerosol, Environ. Sci. Technol., 41, 517-527, doi:10.1021/Es062081q, 2007.

Surratt, J. D., Gómez-Gonzàlez, Y., Chan, A. W. H., Vermeylen, R., Shahgholi, M., Kleindienst, T. E., Edney, E. O., Offenberg, J. H., Lewandowski, M., Jaoui, M., Maenhaut, W., Claeys, M., Flagan, R. C., and Seinfeld, J. H.: Organosulfate formation in biogenic secondary organic aerosol, J. Phys. Chem. A, 112, 8345-8378, doi:10.1021/Jp802310p, 2008.

Surratt, J. D., Chan, A. W. H., Eddingsaas, N. C., Chan, M. N., Loza, C. L., Kwan, A. J., Hersey, S. P., Flagan, R. C., Wennberg, P. O., and Seinfeld, J. H.: Reactive intermediates revealed in secondary organic aerosol formation from isoprene, P. Natl. Acad. Sci. USA, 107, 6640-6645, doi:10.1073/pnas.0911114107, 2010.

Szmigielski, R., Surratt, J. D., Vermeylen, R., Szmigielska, K., Kroll, J. H., Ng, N. L., Murphy, S. M., Sorooshian, A., Seinfeld, J. H., and Claeys, M.: Characterization of 2-methylglyceric acid oligomers in secondary organic aerosol formed from the photooxidation of isoprene using trimethylsilylation and gas chromatography/ion trap mass spectrometry, J. Mass Spectrom., 42, 101-116, doi:10.1002/Jms.1146, 2007.

Treffeisen, R., Tunved, P., Ström, J., Herber, A., Bareiss, J., Helbig, A., Stone, R. S., Hoyningen-Huene, W., Krejci, R., Stohl, A., and Neuber, R.: Arctic smoke - aerosol characteristics during a record smoke event in the European Arctic and its radiative impact, Atmos. Chem. Phys., 7, 3035-3053, doi:10.5194/acp-73035-2007, 2007.

Tuazon, E. C. and Atkinson, R.: A Product Study of the Gas-Phase Reaction of Isoprene with the $\mathrm{OH}$ Radical in the Presence of $\mathrm{NO}_{\mathrm{x}}$, Int. J. Chem. Kinet., 22, 1221-1236, doi:10.1002/kin.550221202, 1990.

Tunved, P., Strom, J., and Krejci, R.: Arctic aerosol life cycle: linking aerosol size distributions observed between 2000 and 2010 with air mass transport and precipitation at Zeppelin station, Ny-Ålesund, Svalbard, Atmos. Chem. Phys., 13, 3643-3660, doi:10.5194/acp-13-3643-2013, 2013.
Walsh, J. E. and Chapman, W. L.: Arctic cloud-radiationtemperature associations in observational data and atmospheric reanalyses, J. Climate, 11, 3030-3045, doi:10.1175/15200442(1998)011<3030:Acrtai>2.0.CO;2, 1998.

Williams, B. J., Goldstein, A. H., Kreisberg, N. M., and Hering, S. V.: In situ measurements of gas/particle-phase transitions for atmospheric semivolatile organic compounds, P. Natl. Acad. Sci USA, 107, 6676-6681, doi:10.1073/pnas.0911858107, 2010.

Zare, A., Christensen, J. H., Irannejad, P., and Brandt, J.: Evaluation of two isoprene emission models for use in a longrange air pollution model, Atmos. Chem. Phys., 12, 7399-7412, doi:10.5194/acp-12-7399-2012, 2012.

Zare, A., Christensen, J. H., Gross, A., Irannejad, P., Glasius, M., and Brandt, J.: Quantifying the contributions of natural emissions to ozone and total fine PM concentrations in the Northern Hemisphere, Atmos. Chem. Phys., 14, 2735-2756, doi:10.5194/acp14-2735-2014, 2014.

Zhang, H. F., Lin, Y. H., Zhang, Z. F., Zhang, X. L., Shaw, S. L., Knipping, E. M., Weber, R. J., Gold, A., Kamens, R. M., and Surratt, J. D.: Secondary organic aerosol formation from methacrolein photooxidation: roles of $\mathrm{NO}_{\mathrm{x}}$ level, relative humidity and aerosol acidity, Environ. Chem., 9, 247-262, doi:10.1071/En12004, 2012.

Zhang, H. F., Lin, Y. H., Zhang, Z. F., Zhang, X. L., Shaw, S. L., Knipping, E. M., Weber, R. J., Gold, A., Kamens, R. M., and Surratt, J. D.: Formation of nanoparticles of blue haze enhanced by anthropogenic pollution, Proc. Natl. Acad. Sci. USA, 106, 17650-17654, doi:10.1073/pnas.0910125106, 2009.

Zhang, R. Y., Wang, L., Khalizov, A. F., Zhao, J., Zheng, J., McGraw, R. L., and Molina, L. T.: Seasonal cycle and temperature dependence of pinene oxidation products, dicarboxylic acids and nitrophenols in fine and coarse air particulate matter, Atmos. Chem. Phys., 10, 7859-7873, doi:10.5194/acp-10-78592010, 2010. 